Bull. Geol. Soc. Finland 42, 165-209 (1970)

\title{
TECTONIC SETTING AND EVOLUTION OF THE MORIN ANORTHOSITE, GRENVILLE PROVINCE, QUEBEC
}

\author{
J. Martignole* and K. Schrijver** \\ *Dépt. de Géologie, Université de Montréal, Canada \\ **Dept. of Geological Sciences, McGill University, Montreal
}

)one essential quality of this bistory [of the anorthosites] is its complexity. ..."

E. H. KRANCK, 1961

\section{ABSTRACT}

The Morin Anorthosite Mass underlies an area of 2500 square kilometers; it consists of three tectonic units: a dome, a diapir and a nappe. The units have in common a large part of their magmatic history, but their tectonic evolution is different. Under the influence of gravity, the dome and the diapir behaved as buoyant masses, while the nappe and part of the diapir spread laterally. Texture and structure of the anorthosite are correlated with these differences in tectonic evolution.

Jotunitic and mangeritic rocks envelope the dome and part of the diapir, whereas a troctolite sill occurs in the zone of weakness between the dome and the nappe. The jotunites and mangerites shared a large part of their tectonic evolution with that of the dome, but while the dome was emplaced in an advanced stage of crystallization, its envelope was largely liquid.

It is probable that anorthosites, jotunites and mangerites are comagmatic, in the widest sense of the word, and it is possible that troctolite was an early differentiate of the parent magma.

The structural relations between the plutonic rocks and the surrounding supracrustal rocks have many characteristics in common with basement-cover relations in polycyclic orogenic zones. However, the plutonites can be considered as a basement complex only if a rather improbable wholesale remobilization of at least the jotunites and mangerites is postulated.

The main phase of penetrative deformation in the supracrustal rocks gave rise to gently inclined and recumbent folds $\left(\mathrm{F}_{2}\right)$ east and northeast of the Morin Mass, and is correlated with the lateral spreading of the anorthosite nappe. This phase overprinted most older structures, but relicts of the latter $\left(\mathrm{F}_{1}\right)$ are preserved locally. A set of major open upright folds $\left(\mathrm{F}_{3}\right)$ is restricted to the area adjacent to the anorthosite nappe and is interpreted as a set of secondorder compression folds related to the emplacement of the nappe. A late phase of deformation gave rise to very gentle major and minor folds $\left(\mathrm{F}_{4}\right)$ that slightly deform the axial lineation of $\mathrm{F}_{2}$-folds.

The regional metamorphism is transitional between the amphibolite and granulite facies; it is roughly contemporaneous with the main phase of deformation, thus with the lateral spreading of the anorthosite nappe. The only well-defined isograd is one that separates orthopyroxene-quartz bearing granulites on the side of the Mass from hornblende-quartz bearing gneisses away from the Mass.

Late metamorphism took place in and around the anorthosite dome and produced garnet and clinopyroxene from plagioclase and iron-rich mafic minerals. 


\section{RESUME}

Le massif d'anorthosite de Morin couvre une superficie de 2500 kilomètres carrés et comprend trois unités tectoniques: un dôme, un diapir et une nappe. Ces trois unités, dont l'origine magmatique est commune, ne doivent leur individualisation qu'à une évolution tectonique tardive, qui se reflète d'ailleurs dans la texture et la structure des anorthosites.

Le dôme et le diapir, entourés par des roches denses, se sont déplacés vers le haut, tandis que la nappe, en contact avec des roches de densité inférieure, s'est étalée latéralement. Sans faire appel à de prétendues forces orogéniques, de tels déplacement de matière peuvent très bien se concevoir par le seul rôle de la gravité.

Un sill de troctolite jalonne la zone de faiblesse entre le dôme et la nappe, tandis que des roches jotunitiques et mangéritiques enveloppent le dôme et une partie du diapir. L'évolution tectonique des mangérites et des jotunites est comparable à celle des anorthosites du dôme, mais alors que ces dernières se mettaient en place dans un état pratiquement cristallin, leur enveloppe restait en grande partie liquide. Il est vraisemblable qu'anorthosites, jotunites et mangérites soient comagmatiques, au sens large du terme, et que la troctolite représente un produit de différenciation précoce.

Les relations structurales entre les roches plutoniques et les roches encaissantes rappellent les relations socle-couverture des zones polycycliques. Cependant les roches plutoniques ne peuvent être considérées comme un socle que si l'on envisage une remobilisation générale des mangérites et des jotunites, ce qui est fort peu probable.

La phase de déformation principale dans les roches encaissantes a donné naissance à des plis couchés $\left(\mathrm{F}_{2}\right)$ à l'Est et au Nord-Est du Massif de Morin: ces déformations sont liées à l'étalement vers l'Est de la nappe d'anorthosite. Cette phase a pratiquement détruit les structures préexistantes dont on ne retrouve que quelques vestiges $\left(\mathrm{F}_{1}\right)$.

Un système de plis droits et ouverts $\left(\mathrm{F}_{3}\right)$ est localisé en bordure de la nappe d'anorthosite et correspond à des plis de second ordre provoqués par des phénomènes de compression au front de la nappe. Enfin des mouvements posthumes ont donné naissance à des ondulations $\left(\mathrm{F}_{4}\right)$ qui déforment localement la linéation contemporaine des plis $\mathrm{F}_{2}$.

Le métamorphisme régional correspond au faciès de transition entre le faciès amphibolite et le faciès granulite. Il est contemporain de la phase principale de déformation, c'est-à-dire de l'étalement de la nappe d'anorthosite. Le seul isograde qui soit bien défini sépare les gneiss quartzofeldspathiques à hornblende des granulites à quartz et orthopyroxène qui se trouvent autour du Massif de Morin.

Un métamorphisme tardif a affecté le massif d'anorthosite et son voisinage immédiat. Il se traduit par la formation de grenat et de clinopyroxène à partir de plagioclase et des minéraux riches en fer.

\section{CONTENTS}

\begin{tabular}{|c|c|}
\hline & \\
\hline 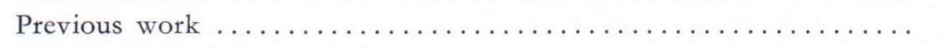 & 0 \\
\hline 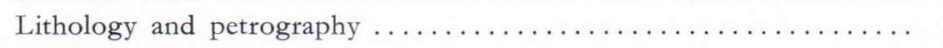 & \\
\hline General statement ....... & \\
\hline Supracrustal rocks . & \\
\hline Plutonic rocks .... & \\
\hline Metam & \\
\hline$y=\ldots \ldots \ldots \ldots$ & \\
\hline upracrustal rocks & \\
\hline in plutonic rocks $\ldots \ldots \ldots \ldots \ldots \ldots \ldots \ldots$ & \\
\hline 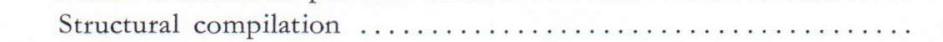 & \\
\hline npilation $\operatorname{map} \ldots \ldots \ldots \ldots \ldots \ldots \ldots \ldots \ldots \ldots \ldots \ldots$ & \\
\hline & \\
\hline Summary and discussion 1 & \\
\hline
\end{tabular}




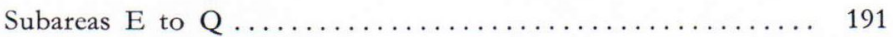

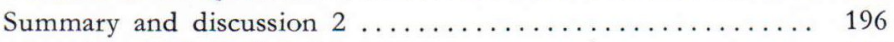

Shape and evolution of major structures ............. 197

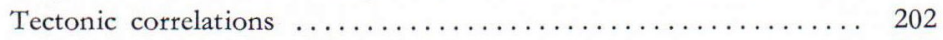

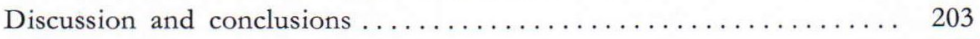

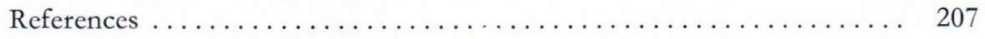

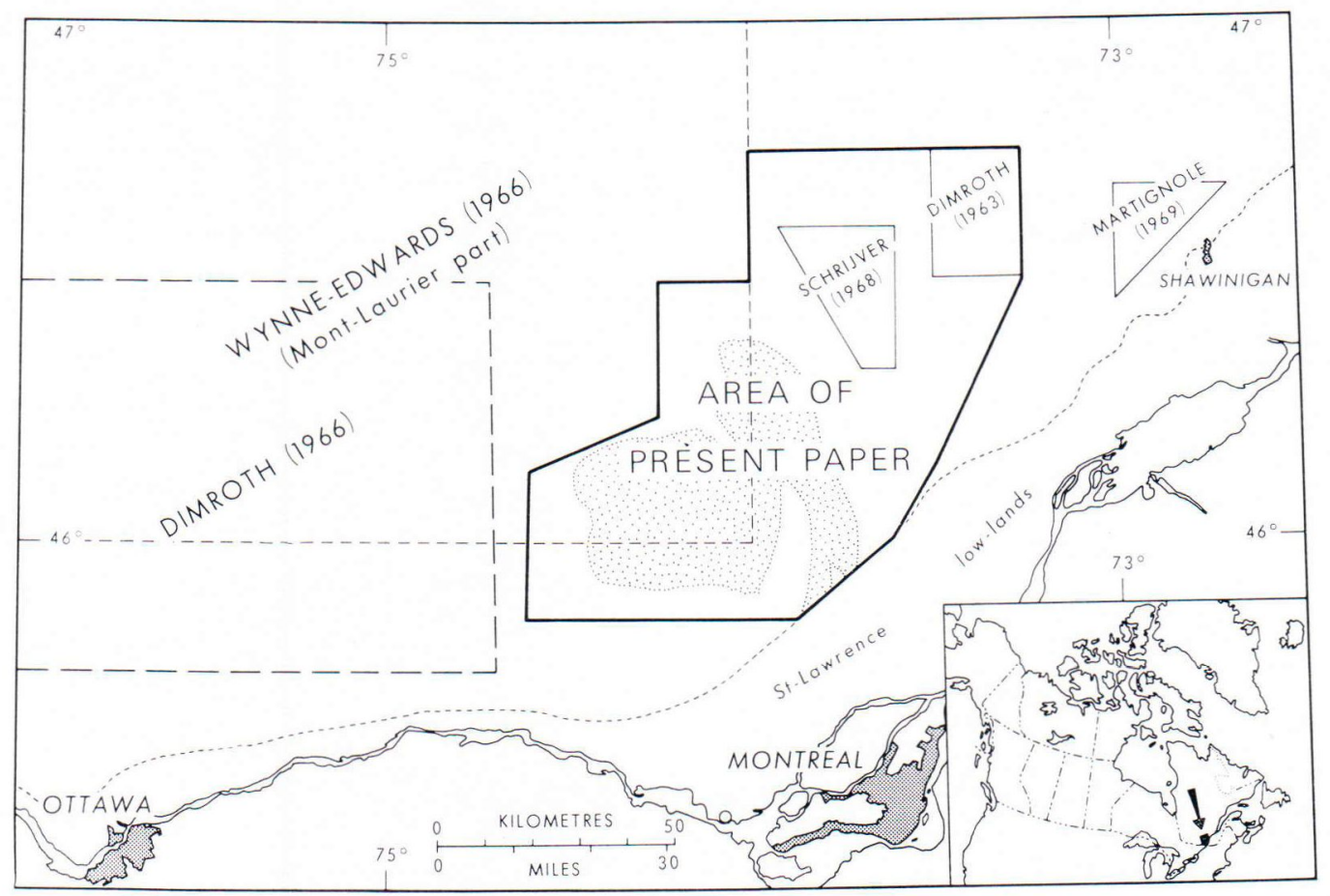

FIG. 1. Index map.

\section{Introduction}

The Morin Anorthosite Mass is one of the numerous bodies of anorthosite in the Grenville province of the Canadian shield. It underlies an area of roughly 2500 square kilometers, the center of which is 75 kilometers northwest of Montreal (Fig. 1), and consists of a Main Body of roughly circular outline and a crescent-shaped Eastern Lobe (Pl. 1). Recently published, firsthand information on the whole Mass does not exist and it seemed useful to outline the present state of knowledge, and to offer a plausible hypothesis of the geological evolution of the Mass, based on a compilation of pertinent information from previous work and our own field and microscopical studies.

We have stressed the tectonic aspects of the geological evolution: it is our opinion that a first step in the unraveling of the undoubtedly long and complex history of the Morin Mass should be a study of geological events more recent than the genesis of the anorthosite.

Tectonic as well as metamorphic features are better developed and easier to study in the layered rocks surrounding the Mass than in the Mass itself or in its associated plutonites. Consequently we have devoted a considerable part of our efforts to a study of the layered supracrustal rocks east and northeast of the Mass, where 
supracrustal rocks and anorthosite are involved in major structures.

The area under consideration (Pl. 1) is hilly and forest-covered; local relief rarely exceeds 200 meters. Bare cliffs are rare and are partly covered by lichen, so that they cannot be studied and mapped by observation through binoculars. Large, clean exposures are scarce, but fresh rock is abundant in numerous roadcuts throughout the area.

Contacts between major lithological units commonly lie in topographic depressions and are covered by thick overburden; despite an intensive search, such contacts have been observed in a few places only.

\section{Previous Work}

The first geological study including and centered on the Morin Anorthosite Mass was made by Adams (1896). The recognition of the close association of the anorthosite with acid plutonic rocks (Osborne, 1936) is perhaps the only observation of fundamental importance that has been added to Adams' thorough work.

The Quebec Bureau of Mines - now Quebec Department of Natural Resources - published a number of maps (1: 63360) and reports over the period from 1934 to 1961 , covering an area completely surrounding and including the Morin Mass.

In 1964, a large area, including the northwestern part of the Mass, was mapped by the Geological Survey of Canada (Wynne-Edwards et al., 1966; see Fig. 1).

Little work other than general mapping has been done in the Morin Mass since Adams (op. cit.) gave his excellent description of the texture and structure of the anorthosite.

Osborne (1949) described various types of anorthosite, including one of the few known intrusive dikes of anorthosite, in the southern part of the Eastern Lobe of the Mass.
Thompson and Garland (1957) made gravity measurements over an area which includes the Mass; they devoted a short section to an interpretation of the negative Bouguer anomaly over the Mass.

Rose (1960) studied iron-titanium oxides in the anorthosite and prepared a small-scale map of the Mass and its surrounding; he showed a gabbroic anorthosite forming a partial rim around, and locally branching into the Main Body.

Papezik (1965) dealt with the geochemistry of major and trace elements in some anorthosite bodies, including the Morin Mass. He made an estimate of the bulk composition of each of two types of anorthosite occuring in the Mass, the "mauve facies» (the coarse-grained type of the Main Body) and the "Chertsey facies» (the fineand medium-grained type of the Eastern Lobe). On the basis of some differences in chemical composition he concluded that it is probable that the two facies are separate intrusions.

Among the studies of areas removed from the Morin Mass but of more than local importance are those by Philpotts, Dimroth, Wynne-Edwards, Martignole, and Schrijver.

Philpotts (1966) gave petrological and mineralogical evidence for the comagmatic relationship of leuconorite and associated jotunitic and mangeritic plutonic rocks occurring in two small bodies, one situated 70 kilometers northeast, and the other 50 kilometers southwest of the Morin Mass. He considered the evidence to be applicable not only to the bodies studied, but to similar "series» throughout the Grenville province, thus including the Morin Mass and associated plutonites.

Dimroth (1966) investigated the style and sequence of deformation over a large area north of Ottawa (Fig. 1), where the tectonic style has presumably not been influenced by plutonic bodies such as those prevailing north of Montreal. Also, his structural analysis (Dimroth, 1963) northeast of the Morin Mass (Fig. 1) is important 
for a synthesis of the structural evolution of the area now under consideration.

Wynne-Edwards et al., (1966) and WynneEdwards (1969) subdivided the rocks underlying an area of 33000 square kilometers into a number of tectonic categories, based on their supposed role during the »Grenville orogeny». They recognized a basement complex, a supracrustal complex (Grenville Group), and pre-, syn- and post-tectonic intrusive rocks. The Morin Mass and associated plutonites are considered to belong to the pre- or early-tectonic category and to be intrusive into the Grenville Group. A line (»composite isograd») is drawn around the rocks making up this category and adjacent rocks (Wynne-Edwards, 1969, p. 168), separating granulite facies assemblages on the side of the plutonites from amphibolite facies assemblages away from the plutonites. The change in metamorphic grade is attributed to some type of contact-metamorphic effect of the plutonites on the surrounding rocks, prior to the regional metamorphism associated with the »Grenville orogeny».

Martignole (1967) recognized two phases of folding in an area 80 kilometers northeast of the Morin Mass. In a later paper (Martignole, 1969) he showed that a small leuconorite-anorthosite body, in the same area, was emplaced after the first phase of folding, but prior to the second phase.

Schrijver (1968) showed that a plutonic complex of acid rocks and minor leuconorite, situated 15 kilometers northeast of the Morin Mass, was deformed and metamorphosed together with adjacent layered gneisses. He posed the problem of basement-cover relations north of Montreal, but failed to find a unique solution.

The close resemblance of the Morin Mass and associated plutonic rocks to the Adirondack Anorthosite and associated rocks of the »syenite series» (Buddington, 1939) invites comparison of hypotheses on the geological evolution of these suites. Comparison is even more tempting because of the probable subsurface continuation of the Morin Mass southward, suggested by rare outcrops of anorthosite as far south as the suburbs of Montreal, and by the occurrence of anorthosite in core from holes drilled through the St-Lawrence lowlands. These occurrences bridge one third of the 150-kilometers gap separating the Morin Mass from the Adirondack Anorthosite.

Therefore, attention is drawn to the recent syntheses of Adirondack geology by Walton and de Waard (1963) and de Waard and Walton (1967). These authors postulated the existence of a basement made up mainly of an anorthositemangerite-charnockite suite of rocks, on which sediments of the Grenville Group were deposited. This hypothesis stands in marked contrast to the formely accepted one, where the anorthosites as well as the syenite series were considered to be intrusive into the Grenville Group (Balk, 1931; Buddington, 1939).

It seems worth keeping both possibilities in mind, in a study of the Precambrian rocks north of Montreal.

\section{Lithology and petrography}

\section{General statement}

Virtually all Precambrian rocks north of Montreal have been subjected to deformation and metamorphism under plutonic conditions, thus most unambiguous evidence bearing on the origin of the rocks has been erased.

Nevertheless, a rough twofold genetic classification into supracrustal rocks and plutonic rocks is employed in this paper. The main criterion on which this classification is based, is the presence or absence of mesoscopic layering. Commonly, sizeable outcrops that show regular, clearly defined layering contain one or more types of rock evidently of sedimentary origin (e. $g$. garnet-sillimanite gneisses). Furthermore, rocks evidently of igneous origin (e. g. subophitic leuconorites) hardly ever show regular meso- 
scopic layering; compositionally different parts in outcrops of plutonic rocks may be roughly tabular and aligned in one preferred direction, but they are commonly patchily distributed and their contacts are vague. Therefore, most well layered rocks are considered to be of supracrustal origin, and most non-layered rocks are probably of deep-seated magmatic origin.

Similar considerations by other workers have led to the general acceptance of the lithostratigraphic terms Grenville Group (or Grenville Series; see Thomson, 1956) and Morin Group (or Morin Series; e. g. Philpotts, 1966) for the meta-sedimentary and meta-igneous rocks respectively. This classification has the disadvantage of implying more than is warranted by the present state of knowledge. Namely, the two groups are poorly defined, even in their type localities, and each occurs in a number of separate bodies which are not known to be homotaxial (American Commission on Stratigraphic Nomenclature, 1961 , pp. 648-9). The absence of top-andbottom criteria in the meta-sedimentary rocks and the complexity of their deformation makes the order of arrangement of different units at any single place a problem in itself, only to be resolved by very detailed mapping of marker horizons combined with structural analysis. This type of work has only recently been started in the part of the Grenville province under consideration (Martignole, 1969).

Although the origin of the rocks is of secondary importance in this paper, some unresolved problems and inconsistencies in our twofold classification as well as in the "group»classification should be pointed out:

(1) Leucocratic granulites (defined according to Watznauer, 1968) and less commonly granofelses, modally similar to intermediate and acid plutonites (mangerites, charnockites) occasionally form mappable homogeneous bodies which grade into conformably interlayered sequences of granulites, pyroxene-amphibolites and metasedimentary rocks. The interlayering is often visible in an outcrop or even in a thin section, and in such cases it seems likely that all components, granulitic as well as other layers, are of supracrustal origin. The homogeneous bodies of granulite may also be of supracrustal origin, but a pre- or syn-tectonic period of anatexis cannot be excluded as an intermediate stage in their development (see also: de Waard and Walton, 1967). In any case, the existence of sedimentary rocks similar in bulk composition to many types of intermediate and acid plutonic rocks is a well known fact. For the time being, all granulites that are not in physical continuity with rocks of demonstrably plutonic origin, are classified with the supracrustal rocks. Here we differ from Wynne-Edwards (1969), who contends that some of these granulites represent the basement on which the "Grenville Group» was deposited. So far, we have found no evidence to support or contradict this hypothesis.

(2) A regular gneissic layering, parallel to the axial planes of folds (see p. 190) is well developed northeast of the Morin Mass. Although this phenomenon is produced by plutonic processes of recrystallization and metamorphic differentiation, it is likely that its development into a regular layering was possible only because of concurrent isoclinal folding of a pre-existing planar structure (bedding?). This occurrence is classed with the supracrustal rocks.

(3) Locally, mobilizates of late- and posttectonic anatexis have formed small bodies of medium- to coarse-grained plutonites (mainly granodiorites). No special class has been erected for these occurrences, as they are too small to show on the maps accompanying this paper.

The tectonic history of the layered supracrustal rocks can be elucidated most effectively by the geometry of their fold patterns. Accordingly, the supracrustal rocks feature in the structural compilation. On the other hand, one of the few means of unraveling the history of the relatively homogenous plutonic rocks is the study of their textural properties, so a considerable section is devoted to this study. 


\section{Supracrustal rocks}

Most maps used in the preparation of the geological compilation map (Pl. 1) show the „Grenville Group» as an undivided unit; even where it is subdivided, correlations are virtually impossible. Consequently, the supracrustal rocks are not subdivided in Plate 1.

Many reasons can be given for the necessity of lumping all supracrustal rocks in one map unit, the most important of which is the scale of mapping. In most previous work it was poorly adapted to the actual complexity of the geology: uniformly 1:63 360 in the heterogeneous supracrustal rocks as well as in the homogeneous plutonites. Rapid alternation of thin beds of different rock types, gradual changes in lithology parallel to the bedding, and repetition and elimination of beds due to deformation (folding, boudinage) necessitate far more detailed mapping, at least in some relatively well exposed ground, before any attempt can be made to elucidate the stratigraphy.

Yet, some features of probable stratigraphic significance are revealed by small-scale maps of very large areas such as those by Wynne-Edwards (1969, Fig. 5) and Engel (1956). Also, in the area covered by Plate 1 , rocks of unambiguously sedimentary origin (quartzites and crystalline limestones) are abundant around the Morin Mass and east of the Mass, whereas other supracrustal rocks (granulites and amphibolebiotite gneisses) are abundant northeast of the Mass.

In the search for the contact of the Morin Mass with adjacent rocks, we noticed time and again the abundance of quartzite at and near the contact of the Mass with the supracrustal rocks, as indicated in Plate 1 by a special symbol. More characteristic is the association of interbedded quartzofeldspathic rocks (leptites and leptynites), quartzites and garnetiferous pyroxene-amphibolites, which can be followed for a distance of approximately fifty kilometers around the Eastern
Lobe of the Mass. Here also, the rock type in direct contact with the Mass or with its thin jotunite rim (see p. 175) is a quartzite.

Despite a lack of knowledge of the exact order of arrangement of the rock types that form the association, we have provisionally raised its status to that of a formation, and call it the LacQuinn Formation (LQF) after its occurrence near Lac-Quinn (see Pl. 1; exact location of outcrop long. $73^{\circ} 43^{\prime} 20^{\prime \prime}$; lat. $45^{\circ} 59^{\prime} 50^{\prime \prime}$ ). The LQF is approximately fifty meters thick. Its lowermost (?), and most persistent, member is a quartzite, and the LQF grades upwards (?) into garnetsillimanite gneisses. The formation does not form a continuous shell around the Mass. The northern boundary of the Main Body is formed by a jotunite, which is overlain by scattered beds of quartzite in a quartzofeldspathic matrix, while the southern boundary of the Main Body, between St-Sauveur-des-Monts and Morin Heights is formed by crystalline limestone. It seems likely that both the scattered beds of quartzite and the crystalline limestone are lateral equivalents of the LQF, but slight discordance cannot be ruled out.

Our field work is not sufficiently extensive to establish what happens to the quartzite-bearing zone in places where mangerites surround the Mass. It is possible that this zone surrounds the entire anorthositic-mangeritic complex, thus resembling somewhat the plutonic basement supracrustal cover relations described by Walton and de Waard (1967). On the other hand, quartzitic and other inclusions are abundant, at least locally, in the plutonic rock adjacent to the Mass, suggesting intrusive relations.

\section{Plutonic rocks}

In most previous work, the plutonic rocks have been subdivided into two major lithological units. Although a complete gradation in modal and chemical composition is probably present (cf. de Waard and Romey, 1969), the actual zone 
of gradation is relatively narrow and separates large homogeneous masses of contrasting rock types: (a) anorthosite and leuconorite, and (b) mangerite and quartz-mangerite (or: farsundite). It is this association of plutonic rocks that, in southern Quebec, is referred to as the »Morin Series».

In the area under consideration, the bulk of the plutonites occurs in and around the Morin Mass, but as shown on the map (Pl. 1), a sizeable body of plutonic rocks (mainly mangerites) is situated northeast of the Mass, and numerous, roughly conformable bodies of leuconorite occur east of the Mass. None of these bodies is connected to the Morin Mass at the present level of exposure. It should be noted that the unique composition of anorthosite and leuconorite facilitates their recognition, but it may well be that strongly deformed, conformable bodies of mangerite have been overlooked in the mapping and classed as granulites with the supracrustal rocks.

The following petrographic description is strictly applicable to the Morin Mass and its adjacent plutonites, but the rocks in the smaller plutonic bodies are similar in many respects to strongly deformed varieties of those in the major occurrence.

A schematic cross section of the boundary of the Mass and adjacent plutonic rocks is given in Figure 2. The section synthetizes observations from a great number of outcrops scattered along the southern and western margins of the Mass. In a direction from east to west, or from north to south, the following rock types and relations are observed:

(1) Coarse-grained mauve to grayish anorthosite and leuconorite. These most abundant rock types in the Main Body consist of plagioclase (andesine to sodic labradorite), orthopyroxene, clinopyroxene, and opaque minerals. Plagioclase ranges from coarse prismatic crystals to fine interlobate grains. The distribution of the dark minerals is extremely variable; perhaps most

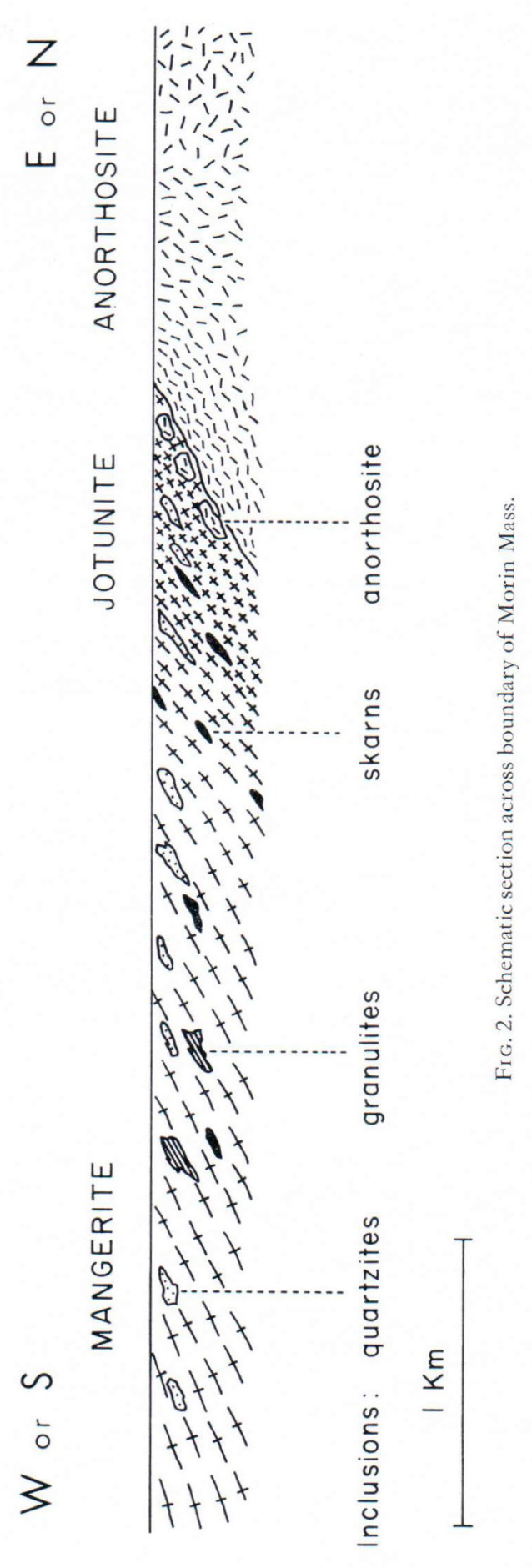

common is their concentration in roughly tabular, vaguely bounded patches, thus giving 


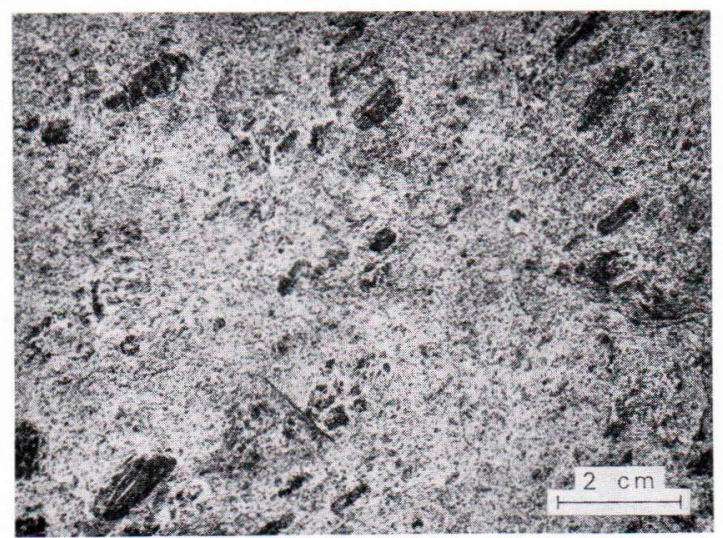

FIG. 3. Plagioclase alignment in anorthosite $\left(\mathrm{S}_{1}^{\prime}\right)$.

rise to continuous gradations from hololeucocratic anorthosite to leuconorite at the scale of an outcrop. Sharply bounded angular to subrounded inclusions of texturally different types of anorthosite in anorthosite, of anorthosite in leuconorite, and, rarely, of leuconorite in anorthosite have also been observed (block structures). Quite common, particularly near the margin of the Main Body, is the curious structure pictured in Figure $24 a$ : numerous spherical or slightly ellipsoidal bodies of subophitic norite (Fig. 4), up to ten centimeters in diameter, are embedded in anorthosite. Since they weather more readily than the anorthosite, a characteristic pitted outcrop surface is formed.

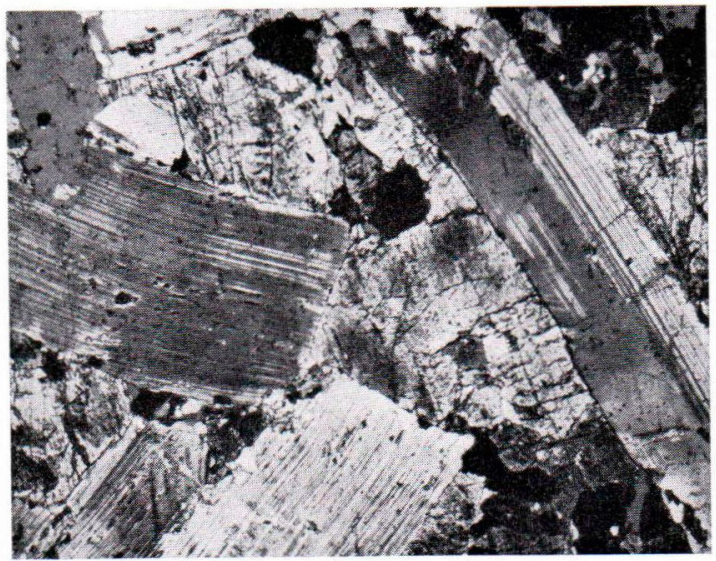

FIG. 4. Undeformed subophitic norite from Main Body. $12 \mathrm{x}$. (in this and the following photomicrographs nicols are crossed).
In anorthositic-leuconoritic rocks, where coarse prismatic plagioclase crystals are an important constituent, cumulate textures can occasionally be observed. With increasing abundance of dark minerals, plagioclase orthocumulates, mesocumulates and adcumulates can be recognized (Wager and Brown, 1968, p. 65). On large, clean exposures of such rocks, albite and carlsbad twins, and a preferred orientation of plagioclase (010) faces can be seen (Fig. 3); there is little doubt that this orientation is a magmatic, depositional fabric.

Granulation and recrystallization interfere with the recognition of primary textures and structures. In fact, it is uncommon to find relatively undeformed rocks such as pictured in Figure 5, even in the Main Body, although deformation is nowhere as intense as in the Eastern Lobe, where vestiges of a primary fabric are extremely rare (Fig. 7). In general, in the Main Body, an important part of the rock is made up of fragments of large plagioclase crystals and fine interlobate to saccharoidal plagioclase grains, all of which are evidently products of the disintegration of large crystals (Fig. 6). Both granulation (purely mechanical disintegration) and recrystallization played a role in the defortion, but it is rare that the effects of these processes can clearly be separated.

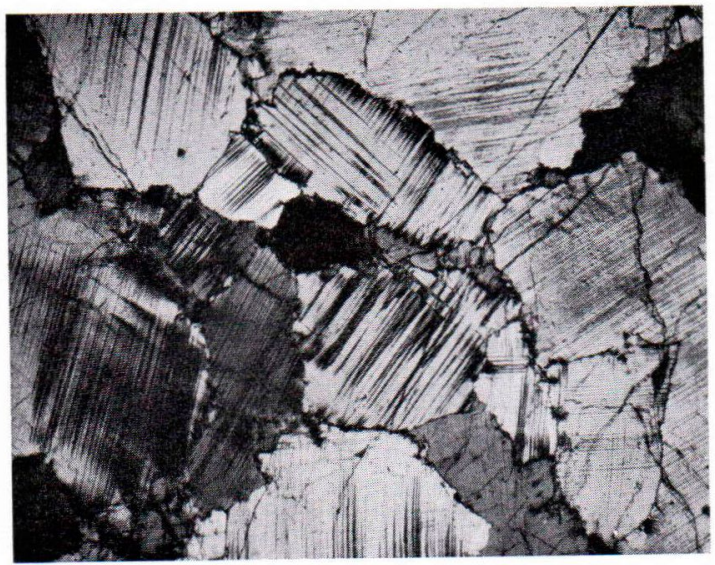

FIG. 5. Slightly deformed anorthosite from Main Body. $12 \mathrm{x}$. 


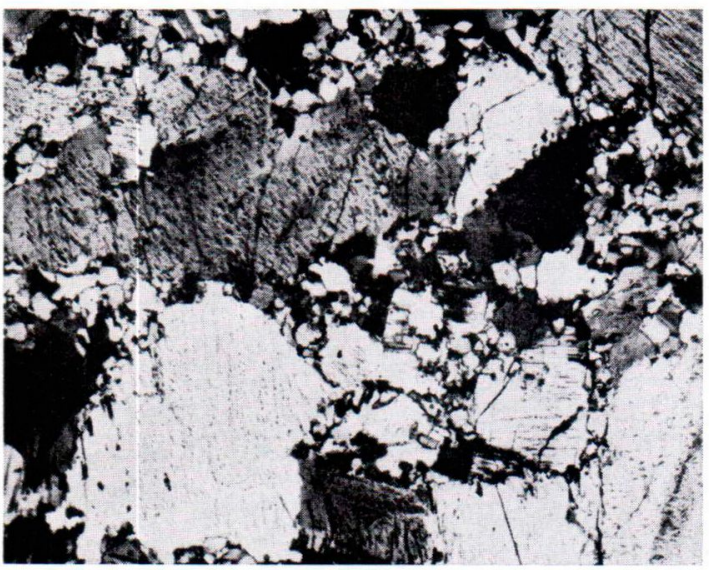

FIG. 6. Mortar texture in deformed anorthosite from Main Body. 30x.

With respect to this distinction, it is of interest to consider the color of the plagioclase: in thin section, the coarse plagioclase of the mauve anorthosite is pinkish and contains innumerable minute inclusions (»dust»). The finer plagioclase grains are either pinkish and dusty, or they are colorless and clean, with intergranular aggregates of opaque minerals, presumably formed by expulsion of the minute inclusions ( $c f$. Philpotts, 1966 , pp. $24-5)$. The expulsion of the inclusions is undoubtedly directly related to recrystallization, the colorless plagioclase grains commonly being polygonal. Thus, the color of the plagioclase is a rough measure of its degree of recrystallization. Similar to the behaviour of the inclusions is that of potassium feldspar: originally in solid solution in the plagioclase prisms, it can be exsolved and expelled from the plagioclase with increasing recrystallization and occurs in the fine intergranular aggregates together with clear plagioclase and opaque grains.

It has been stressed by Osborne (1949) that large intergranular movements did not necessarily accompany the disintegration of plagioclase crystals. This is illustrated by the occasional preservation of the original prismatic, or at least elongate, shape of large plagioclase crystals, presently occupied by aggregates of small polygonal grains. Clearly, the disintegration of

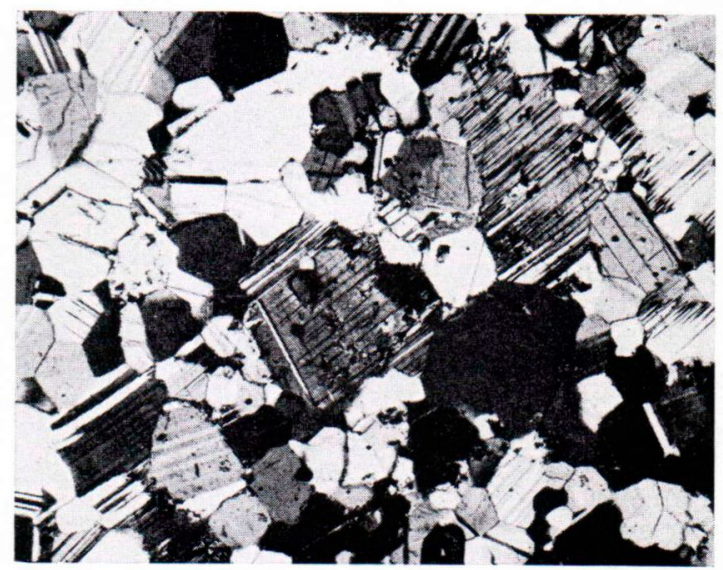

FIG. 7. Plagioclase relict in recrystallized anorthosite from Eastern Lobe. 45x.

large plagioclase crystals cannot simply be called »granulation».

Nevertheless, it is possible that purely mechanical forces initiated the deformation of the anorthosite by bending of the plagioclase crystals and that stress release was afforded partly by granulation and partly by recrystallization.

Apparently, judging by the preservation of primary fabric elements, the deformation in the

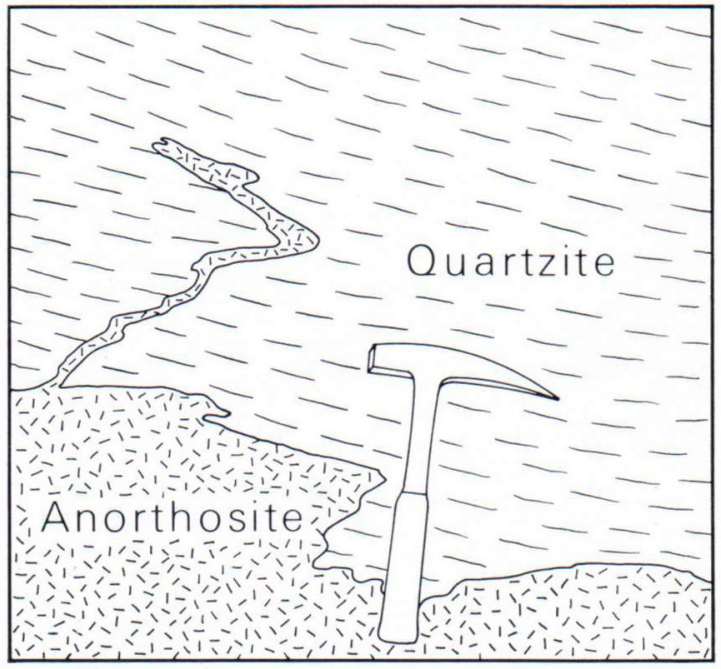

FIG. 8. Anorthosite-leuconorite stringer cutting across and folded together with quartzite (long. $74^{\circ} 03^{\prime} 30^{\prime \prime}$; lat. $\left.46^{\circ} 12^{\prime} 00^{\prime \prime}\right)$. 


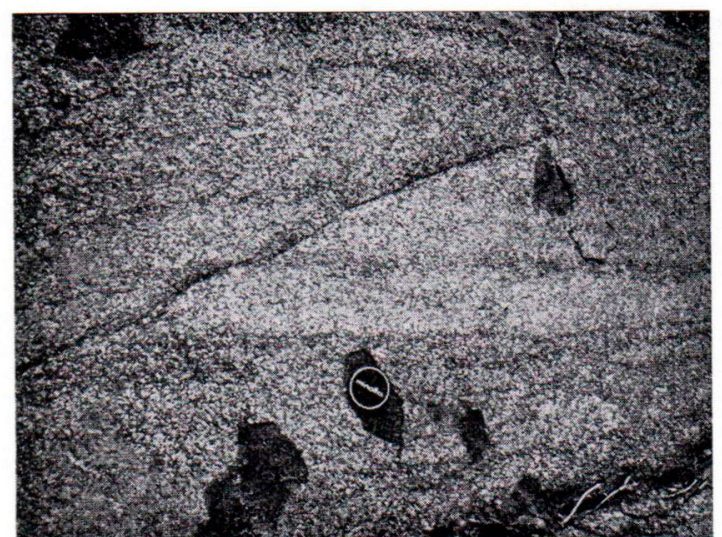

FIG. 9. Inch-scale layering in ferrogabbro.

Main Body was of a different nature and/or less intense than that in the Eastern Lobe ( $c f$. Figs. 6 and 7$)$.

In distinction with the lithological units to be described next, small xenoliths have not been observed in the Mass, although a few large, mappable bodies of supracrustal rocks (mainly quartzites) are present in the Main Body (see Pl. 1). At the contact of one of these bodies, a five-centimeters wide offshoot of leuconorite (approximately ten percent dark minerals) cuts across and is folded together with quartzite (Fig. 8).

(2) Jotunite. A narrow jotunite zone is commonly present around the Mass (Pl. 1, Fig. 2). The contact zone between anorthosite and jotunite is occupied by an oxide-clinopyroxenerich gabbroic layer, a few meters thick. An interesting but unique occurrence of inch-scale layering in this gabbro is present along Highway 30, seven kilometers south of Lac Archambault (Fig. 9).

The gabbro encloses angular to subangular blocks of anorthosite and grades into jotunite with numerous small xenoliths of quartzite and calc-silicate rocks (Figs. 10, 11). A few small dikes of jotunite have been observed in quartzite,

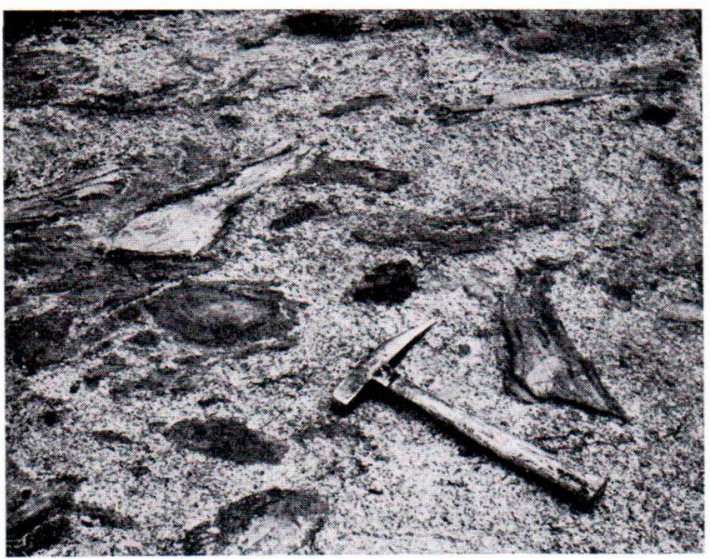

FIG. 10. Quartzite and calc-silicate inclusions in jotunite; inclusions exceptionally non-oriented and rotated. West side of Lac Archambault.

just northeast of Wexford lake; otherwise dikes of jotunite are absent.

Both gabbro and jotunite contain garnet, the main part of this lithological unit lying between the garnet isograds 3 and 4 (Pl. 1).

The jotunite is a dark, heavy rock, rich in irontitanium oxides and apatite. Where it is not too strongly deformed and gneissic, it has a palimpsest structure due to the growth of reaction rims of garnet, quartz and locally, clinopyroxene, around plagioclase grains. Mauve or greyish plagioclase occurs either as strained megacrysts dotted with inclusions, or as composite augen formed by a

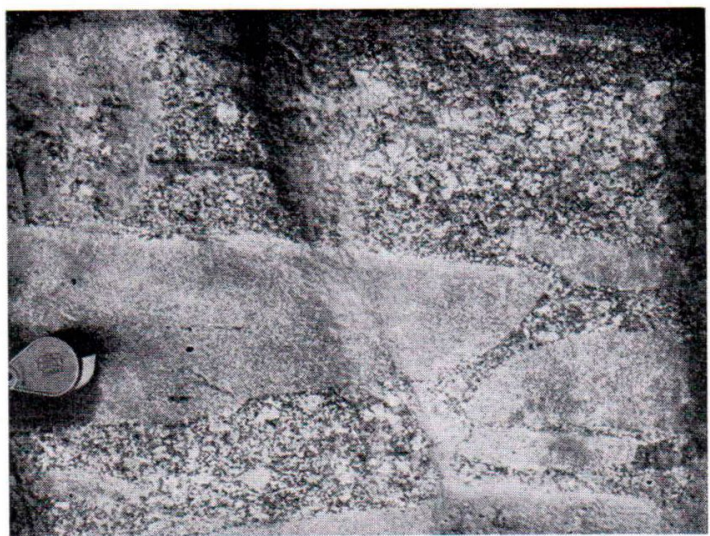

FIG. 11. Quartzofeldspathic inclusions in jotunite. Wexford lake. 


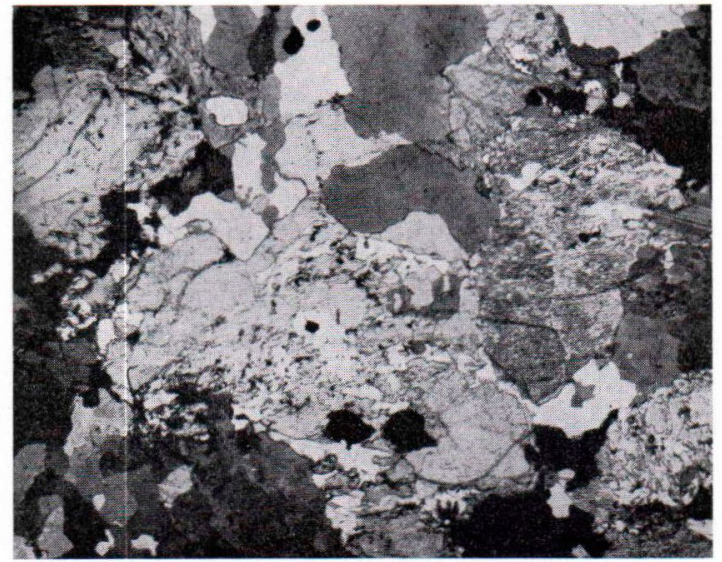

FIG. 12. Hypidiomorphic-granular texture in undeformed mangerite. $12 x$.

great number of small unstrained polygonal plagioclase grains (Fig. 14). Orthopyroxene is commonly present, and like plagioclase, is rimmed by garnet, quartz and clinopyroxene.

It is clear that the texture of the jotunite is a composite one, in which deformed magmatic textures and secondary textures cannot be separated and studied with the same ease as those in the anorthosite.

(3) Mangerite and quartz-mangerite. The contact between jotunite and mangerite (Fig. 2) cannot be shown by a line, the change in mineralogy being completely gradational. The mangerites are not as closely associated with the Mass as the jotunites. The area covered by Plate 1 is too small to show this clearly, but Wynne-Edwards' maps (1969) substantiate this statement.

The mangerites are generally strongly deformed, and as stated before, they are difficult to distinguish from supracrustal leucocratic granulites. Nevertheless, the hypidiomorphicgranular texture of rare undeformed mangerites (Fig. 12), the occasional presence of albitecarlsbad twinned plagioclase porphyroclasts in in the common deformed varieties, and the occurrence (very rare!) of inverted pigeonite, leave little doubt about the igneous origin of these rocks.

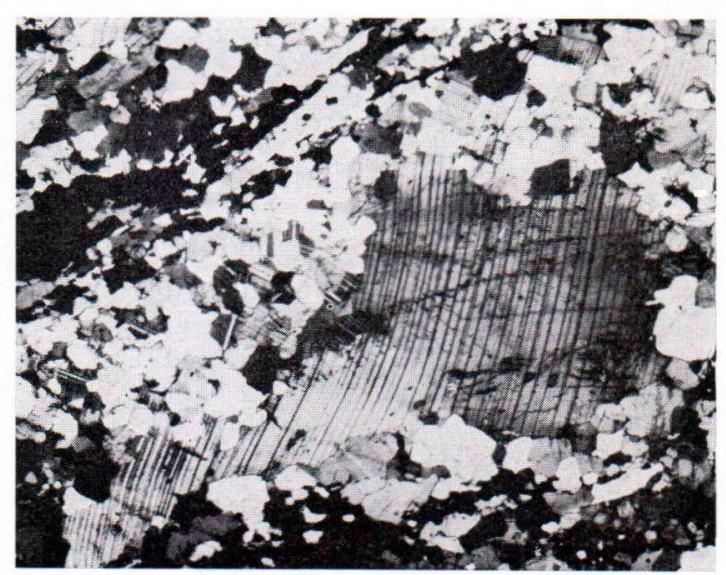

FIG. 13. Plagioclase porphyroclast in deformed mangerite. $12 x$.

Small tabular, commonly well aligned xenoliths of quartzite, calc-silicate rocks, quartzofeldspathic granulites, and pyroxene-amphibolites are present in the mangerites, although not as abundantly as in the jotunites. The distribution of the xenoliths is erratic: some outcrops contain swarms of inclusions and others contain few or none.

Thin dikes (very rare!) of strongly deformed quartzofeldspathic rocks, possibly mangerites, cut the anorthosite (e.g. north shore of Patrick lake, long. $73^{\circ} 58^{\prime} 20^{\prime \prime}$; lat. $46^{\circ} 06^{\prime} 40^{\prime \prime}$ ), but dikes of mangerite have not been observed in the supracrustal rocks.

The undeformed mangerites are found southwest of the Mass. From west to east, along the southern margin of the Mass, textural evidence of deformation increases and the rocks attain their common porphyroclastic habit. Large plagioclase porphyroclasts (Fig. 13) or composite plagioclase augen are surrounded by thin discontinuous stringers of quartz, orthopyroxene, clinopyroxene, hornblende, magnetite and apatite. Garnet is a common constituent between the garnet isograds ( 3 and 4 on Pl. 1); it occurs in reaction rims between plagioclase and magnetite or hypersthene.

By further flattening of the plagioclase augen and the development of genuine Plättungsquarz 


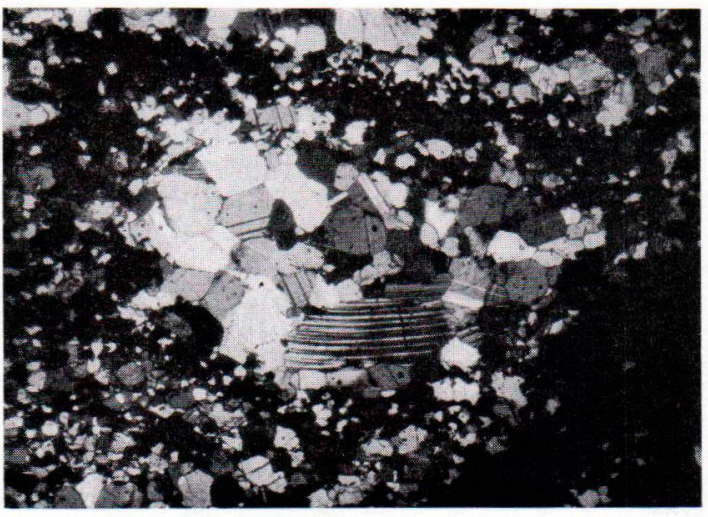

Frg. 14. Composite plagioclase auge in garnetiferous jotunite. $12 \mathrm{x}$.

(Fig. 15), the texture becomes granulitic with alternating stringers of quartz, and feldspathic and mafic components. This stage is reached along the eastern border of the Main Body.

Along the western border of the Lobe, a diablastic troctolite forms a relatively thin, but mappable layer. This is the only occurrence of troctolite in the area. Although the rock is folded, foliated and lineated, primary inch-scale layering (pure anorthosite alternating with mafic-rich layers) is well-preserved in many outcrops. The reader is referred to Osborne (1949) for a petrographic description of the troctolite and the two thin anorthosite dikes cutting across the troctulite.

In summary, a great variety of textures is present in the plutonic rocks. Many originated during synkinematic metamorphism or were strongly modified by this process. Differences in the intensity of deformation (textural evidence) can be correlated, to some extent, with the composition of the rocks: those rich in quartz, such as quartz-mangerites, are commonly strongly deformed, whereas rocks devoid of quartz are less deformed. But, in any one rock type, great complexity in the development of the texture

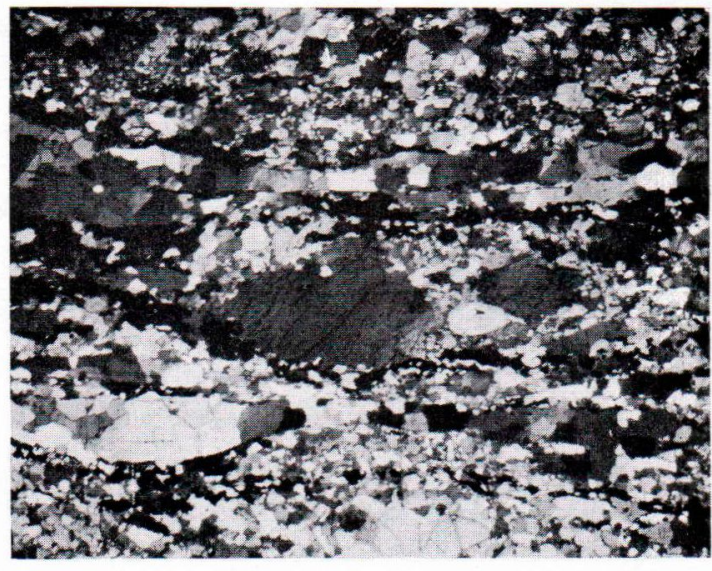

FIG. 15. Granulitic texture in strongly deformed mangerite. $12 x$.

is indicated by the occurrence of fundamentally different textures side by side. In the most general terms, a series of processes varying in intensity from place to place and from time to time, including magmatic crystallization, protoclasis, metamorphic recrystallization, tectonic deformation and cataclasis has occurred, each process leaving its imprint, in one way or another, on the resulting texture. Simple textures, such as subophitic and granoblastic, are clearly the result of the last, most intensive process only. Others contain elements of various processes, and by classifying such composite textures from various localities into groups, it is possible to build up a picture of the development of one simple texture from another.

More important than the classification in itself is its applicability to the gradual change in texture across the plutonites. In particular, the gradual change in texture from the coarse, generally dark-coloured anorthosite in the Main Body (in the literature also referred to as the "mauve facies" or the "Ashton facies") to the fine, generally light-coloured anorthosite in the Eastern Lobe (also referred to as the »Chertsey facies») must be taken into account in any hypothesis on the emplacement and deformation of the Morin Mass. 


\section{Metamorphism}

After the section on structural geology, it will be shown that it is possible to correlate, to some extent, deformation, metamorphism and intrusion (p. 206). Therefore, a brief description of metamorphic assemblages is given here, based on a microscopical study of approximately eighthundred thin sections and limited work with the universal stage and immersion oils.

This primitive stage of the study of metamorphism is due mainly to the absence of published information on mineral assemblages: in most previous work, a great variety of minerals is mentioned, but important questions such as which minerals occur consistently together, and which minerals are mutually exclusive have been considered only by Dimroth (1963).

Fabric and mineralogy of all supracrustal and many plutonic rocks in the area indicate highgrade metamorphism. Diagnostic mineral assemblages are generally characteristic of metamorphism transitional between the amphibolite and granulite facies (Turner, 1968, p. 320).

The texture of some supracrustal rocks is reminiscent of that in contact-metamorphic aureoles: most crystalline limestones and many pyroxene-amphibolites have a saccharoidal granoblastic texture. However, interlayered quartzbearing rocks are invariably foliated and lineated, and have textures ranging from interlobate to amoeboid, and from eugranoblastic to porphyroblastic. Also mineralogically, some rocks are similar to those in contact-metamorphic aureoles, but only corundum occurs exclusively, but very rarely, at the contact of plutonic and supracrustal rocks (respectively leuconorite and garnet-biotite gneiss: see Pl. 1). It is perhaps significant that two out of three cordierite-bearing rocks, and three out of four wollastonite-bearing rocks occur very close to, or at the contact of, plutonic rocks (see P1. 1).

In the field, it was possible to trace four lines or narrow zones, numbered 1 to 4 on Plate 1 , on either side of which one or more rock types differ in mineralogy, presumably independent of bulk composition. The existence of these lines, provisionally referred to as »isograds», was substantiated by thin section study, but the distribution of sample locations over the area is not sufficient to "map» other isograds by laboratory study.

Isograd 1 encloses a small portion of the area. Inside the isograd ortbopyroxene is present in common leucocratic quartz-bearing rocks, whereas outside the isograd orthopyroxene is absent from such rocks. Some other differences between assemblages on either side of this isograd, are:

(a) In leucocratic, quartz-bearing rocks, garnet is present, mostly in symplectitic intergrowths with quartz. These symplectites commonly occur between plagioclase and iron-oxide, and less commonly between plagioclase and hypersthene (cf. de Waard, 1965). Clearly, at least plagioclase and iron-oxide are reactants, and garnet and quartz are products.

(b) Garnet is also present in meta-gabbros and amphibolites inside isograd 1, but does not participate in any obvious reaction relations.

(c) Hornblende is invariably brown, in the leucocratic rocks as well as in the amphibolites, whereas brown hornblende is, at most, a rarity elsewhere in the area. In meta-gabbros and amphibolites, brown hornblende forms coronas around iron (-titanium)-oxides, in particular at contacts of the latter with pyroxenes.

Isograd 2 separates migmatitic bornblende-biotite gneisses (northwest) from orthopyroxene-bearing granulites (southeast). The former do not contain orthopyroxene, but the latter do contain hydrous minerals, in fact, locally exclusively so. Similarities and differences between mineral assemblages on either side of this isograd in rocks of greatly varying bulk composition are indicated in Tables 2 and 3.

Isograds 3 and 4, representing the same mineralogical changes, enclose a large part of the Morin Mass and its surrounding plutonites. Between these isograds, the jotunites and 
mangerites commonly contain garnet; locally, leuconorite and anorthosite also contain garnet. The garnet is, in most cases, clearly a reaction product of plagioclase and iron oxide, or plagioclase and hypersthene. Next to garnet, quartz and locally clinopyroxene are recognizable as reaction products by their occurrence in symplectitic coronas between the reactants ( $c f$. de Waard, 1965). Thus, the reaction is very similar to the one described above (isograd 1).

The reaction relations are most commonly and most clearly developed in the iron-rich jotunites, but even in these rocks the occurrence of garnet is very erratic. Some parts of outcrops or even thin sections may be devoid of garnet and display many hypersthene-plagioclase contacts, whereas in other parts of these domains hyperstheneplagioclase boundaries are occupied by garnetquartz(-clinopyroxene) symplectites. It is rare to find rocks in which the garnet-forming reaction has gone to completion, and even then, the rock still shows the typical symplectitic intergrowths.

Similar intergrowths, due to the same reaction, have been observed in a relatively small number of outcrops of iron-rich rocks throughout the zone bounded by isograds 3 and 2, but none of these occurrences is of mappable size.

Mineral intergrowths indicative of partial retrogression - or rather, hydration - are very common. The common occurrence of such minerals as calcite, chlorite and sericite in orthopyroxene-bearing rocks does not unduly complicate the characterization of the high-grade assemblages. However, the occurrence (recurrence?) of minerals such as hornblende and biotite, which may have been stably associated with orthopyroxene, even at the peak of high-grade metamorphism, makes it difficult to establish which minerals form a paragenetic assemblage (i. e. an association of minerals formed more or less simultaneously at one particular combination of environmental conditions). Therefore, in the following tables, only those minerals are dis- regarded that are obviously products of lowgrade metamorphism, and that occur in small amounts, in anhedral patches. Thus, the assemblages recorded are not necessarily paragenetic; indeed, some are necessarily not paragenetic.

The following tabulated assemblages (Tables 1 to 4 ) are from the supracrustal rocks in the area bounded by isograd 1 in the northeast, and by isograd 3 in the southwest. Assemblages that

TABLE 1.

Basic assemblages (71) between isograds 1 and 3

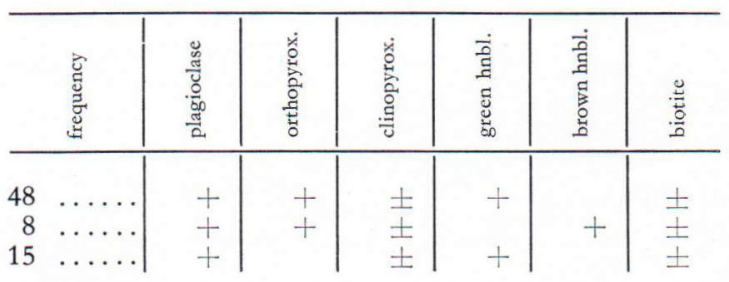

+ present; \pm present or absent

TABle 2.

Quartzofeldspathic assemblages (192) between isograds 1 and 3

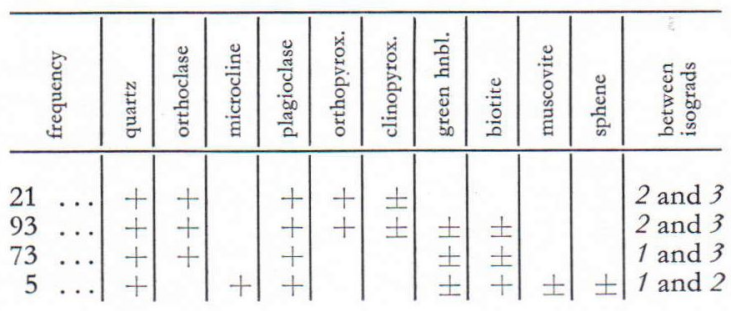

TABLE 3.

Semi-pelitic and pelitic assemblages (109) between isograds 1 and 3

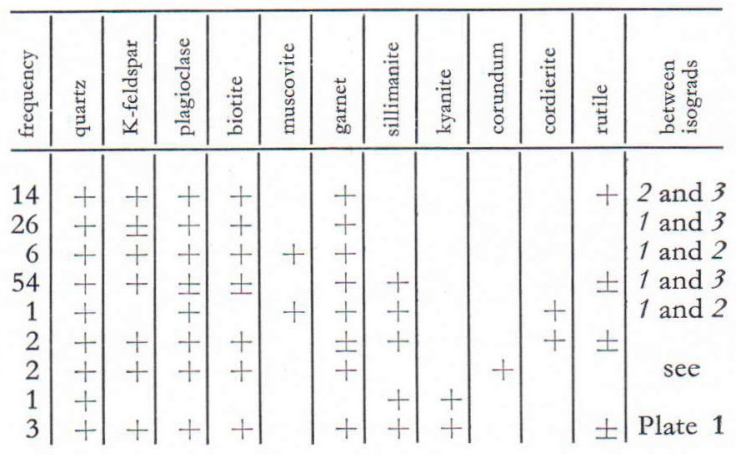


TABLE 4.

Minerals in calcareous assemblages between isograds 1 and 3

\begin{tabular}{|c|c|c|c|}
\hline $\begin{array}{l}\text { diopside } \\
\text { sphene } \\
\text { scapolite } \\
\text { calcite } \\
\text { quartz } \\
\text { plagioclase } \\
\text { K-feldspar }\end{array}$ & $\begin{array}{l}\text { phlogopite } \\
\text { biotite } \\
\text { hornblende } \\
\text { dolomite } \\
\text { forsterite } \\
\text { spinel } \\
\text { garnet }\end{array}$ & $\begin{array}{l}\text { wollastonite } \\
\text { cummingtonite } \\
\text { vesuvianite } \\
\text { epidote } \\
\text { chondrodite } \\
\text { clinohumite } \\
\text { sinhalite }^{1} \text { ) }\end{array}$ & $\begin{array}{l}\text { Fe-oxides } \\
\text { graphite } \\
\text { pyrite } \\
\text { pyrrhotite }\end{array}$ \\
\hline
\end{tabular}

1) see Tröger, 1967, p. 275

occur exclusively northeast or southwest of isograd 2 are indicated in the tables and in the summary descriptions.

Mafic assemblages are defined as those with more than thirty-five percent dark minerals, amongst which either amphibole or pyroxene is the dominant one. On either side of isograd 2, the same mafic assemblages are present, commonly with two or three mafic minerals, and rarely with four. Plagioclase ranges from $\mathrm{An}_{25}$ to $\mathrm{An}_{40}$ (U-stage). Additional phases, besides the tabulated ones, are apatite, zircon, opaque minerals and traces (less than one-third percent) of potassium feldspar and quartz.

Quartrofeldspathic assemblages are those in which quartz and feldspar dominate. They contain less than thirty percent dark minerals, amongst which either amphibole or pyroxene is the dominant one. (Quartzofeldspathic rocks containing garnet and biotite, and lacking amphibole and pyroxene, are classed as »semi-pelites» below). Orthopyroxene-bearing assemblages are present only southwest of isograd 2, whereas microcline \pm muscovite assemblages only occur northeast of that isograd. Commonly, two mafic minerals are present, but three are not rare, and up to four have been observed. Additional phases, besides the tabulated ones, are apatite, zircon and opaques.

Semi-pelitic assemblages are those that consist of quartz, feldspars, garnet, and biotite, whereas pelitic assemblages contain the same minerals and an aluminum-silicate, generally sillimanite. Kyanite-, corundum-, and cordierite-bearing assem- blages are so rare that they could be plotted on the map (Pl. 1). For the original description of the presence of kyanite in this part of the Grenville province, the reader is referred to Martignole and Schrijver (1968).

The only assemblages that are indicative of a metamorphic grade lower than that of the rocks southwest of isograd 2, are the muscovite-bearing ones. Note that the muscovite + cordierite assemblage does not contain potassium feldspar.

Additional phases, besides the tabulated ones, are apatite, zircon, graphite, other opaque minerals and green spinel. Spinel and corundum occur only as inclusions in garnet. Potassium feldspar is commonly perthitic orthoclase, but perthitic microcline may be present.

Calcareous assemblages. A great variety of minerals in numerous combinations has been observed in calcareous assemblages. From fortytwo hand specimens, thirty-eight different assemblages have been determined. The minerals, in approximate order of frequency of occurrence, are given in Table 4.

It is probable that forsterite occurs exclusively southwest of isograd 2, but an insufficient number of specimens is available from the area northeast of that isograd, to be certain about this.

Scapolite + plagioclase, microcline, epidote, and hornblende are present in calcareous assemblages only northeast of isograd 2 .

TABle 5.

Assemblages in plutonic rocks (167), mainly from LacCroche plutonic Complex, between isograds 2 and 3

\begin{tabular}{|c|c|c|c|c|c|c|c|c|c|c|c|}
\hline & 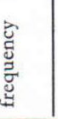 & 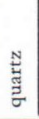 & 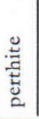 & $\begin{array}{l}\frac{\mathscr{D}}{d} \\
\frac{\pi}{d} \\
\frac{0}{60} \\
\frac{\pi}{0}\end{array}$ & 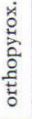 & 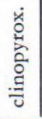 & 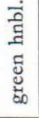 & .ֶّ & 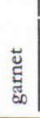 & . & 䓀莒 \\
\hline $\begin{array}{r}41 \\
2 \\
\end{array}$ & $\begin{array}{l}\ldots \\
\ldots\end{array}$ & & \pm & $\begin{array}{l}+ \\
+ \\
\end{array}$ & $\begin{array}{l}+ \\
+ \\
\end{array}$ & $\begin{array}{l}+ \\
+\end{array}$ & + & + & & + & $\begin{array}{l}\text { leuco- } \\
\text { norite }\end{array}$ \\
\hline $\begin{array}{r}76 \\
7 \\
\end{array}$ & $\begin{array}{l}\ldots \\
\ldots \\
\end{array}$ & $\begin{array}{l}+ \\
+ \\
\end{array}$ & $\begin{array}{l}+ \\
+ \\
\end{array}$ & $\begin{array}{l}+ \\
+ \\
\end{array}$ & $\begin{array}{l}+ \\
+ \\
+\end{array}$ & $\begin{array}{l}+ \\
+ \\
\end{array}$ & $\begin{array}{l}+ \\
+ \\
\end{array}$ & & + & & $\begin{array}{l}\text { quartz- } \\
\text { mangerite }\end{array}$ \\
\hline $\begin{array}{r}15 \\
15 \\
6 \\
3 \\
2\end{array}$ & $\begin{array}{l}\ldots \\
\ldots \\
\ldots \\
\ldots \\
\ldots\end{array}$ & & $\begin{array}{l}+ \\
+ \\
+ \\
+ \\
+\end{array}$ & $\begin{array}{l}+ \\
+ \\
+ \\
+ \\
+\end{array}$ & $\begin{array}{l}+ \\
+\end{array}$ & $\begin{array}{l}+ \\
+\end{array}$ & $\begin{array}{l}+ \\
+\end{array}$ & $\begin{array}{l}+ \\
+\end{array}$ & & & mangerite \\
\hline
\end{tabular}


Table 5 shows mineral assemblages of plutonites, mainly from the Lac-Croche plutonic Complex. Additional phases, besides the tabulated ones, are zircon, apatite, opaques, and in quartz-mangerites, orthite. Leuconorites and mangerites generally contain a trace of quartz.

The similarity in metamorphic grade between supracrustal rocks and plutonic rocks is brought out by a comparison of Tables 2 and 5 .

\section{Structural geology}

\section{Fabric elements in supracrustal rocks}

The bulk of the structural data consists of measurements of orientations of a few types of penetrative fabric elements. In the supracrustal rocks northeast and east of the Morin Mass, the geometrical relations between these elements and minor folds are well known. Elsewhere in the area, supracrustal rocks are not abundant, and our observations are too scarce to give a general description of the relation between their fabric elements and minor folds.

Ideally, three types of planar fabric elements, penetrative on the scale of a thin section, hand specimen or outcrop, can be distinguished in the supracrustal rocks: bedding, bedding foliation, and axial-plane foliation.

The recognition of bedding is based on circumstantial evidence only, since depositional fabrics, such as grading, have not been observed. It is probable that regular sequences of layers consisting of rocks of unambiguously sedimentary origin, such as quartzites, garnet-sillimanite gneisses or crystalline limestones, represent bedding. Commonly, basic rocks and quartzofeldspathic rocks are conformably interlayered in such sequences. The beds range in thickness from a centimeter to a few meters.

Bedding foliation denotes a planar alignment of grains and small aggregates of grains parallel to the bedding. Quartz lenticles (Plättungs- quarz), biotite flakes, and aggregates of dark minerals take part in this alignment; it is commonly the most conspicuous fabric element in thin section and hand specimen. In the hinge zones of minor folds, however, the quartz lenticles and some or all other elements forming the bedding foliation are oriented parallel to the axial planes of the folds. Since most minor folds are nearly isoclinal, it is only in their hinge zones that bedding foliation (folded) can occasionally be distinguished from axial-plane foliation (not folded). It is clear that the bedding foliation is older than the axial-plane foliation; accordingly, the former is denoted by $\mathrm{S}_{1}$ and the latter by $\mathrm{S}_{2}$.

The degree of development of $\mathrm{S}_{2}$ changes greatly over the area, from simple parallelism of quartz lenticles, only visible under the microscope, to a truly gneissic layering and pervasive foliation, which is very hard or impossible to distinguish from bedding and bedding foliation. Thus, it is rare that bedding and $S_{1}$ as well as $\mathrm{S}_{2}$ can be recognized in any one outcrop: a common entry in field notebooks is "unassigned foliation and layering».

Presumably, both $S_{1}$ and $S_{2}$ formed at different times during the deformation of the rocks. $\mathrm{S}_{2}$ is obviously geometrically related to the minor folds described below. $S_{1}$ might be taken as evidence for an old pre- $\mathrm{S}_{2}$ generation of isoclinal folds, or it is a mimetic fabric developed parallel to a sedimentary fabric or concentric cleavage (Savage, 1967; de Sitter, 1964, p. 292). We will return to this point on page 190 .

A mineral lineation is invariably present on $\mathrm{S}_{1}$ and $\mathrm{S}_{2}$, and where these planes intersect, the lineation is parallel to the intersection (Fig. 26). The lineation is defined by preferred formorientation of the long axes of most grains and aggregates of grains, in particular of quartz lenticles, sillimanite prisms, and aggregates of pyroxene and hornblende grains.

Although this lineation is virtually the only one observed, it has been called $\mathrm{L}_{2}$ because it 
probably developed simultaneously with $\mathrm{S}_{2} \mathrm{du}-$ ring the formation of the minor folds $\left(\mathrm{F}_{2}\right)$ to be described next.

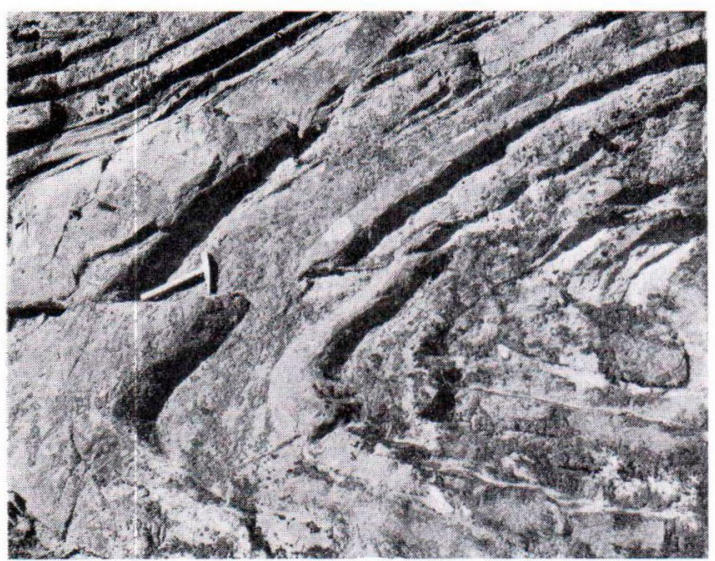

FIG. 16. Large $F_{2}$-fold: northern extension of Rawdon nappe. Subarea J. (Photo Office du Film du Québec)

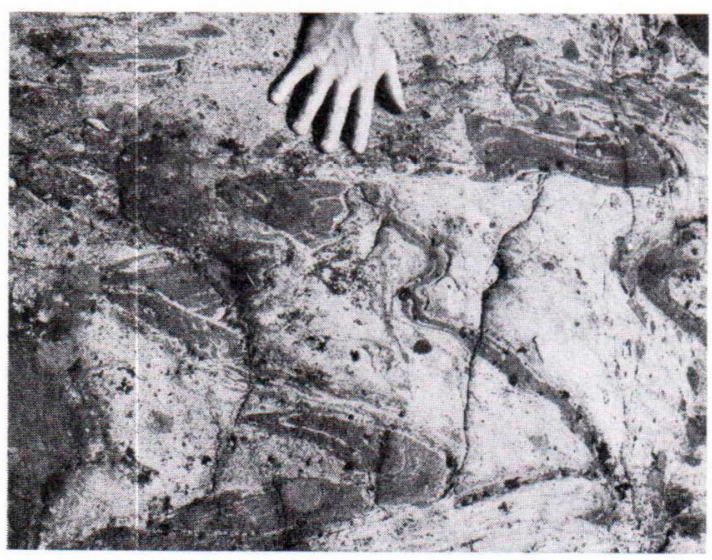

FIG. 18. Relict $\mathrm{F}_{2}$-folds in banded granulites. Subarea A.

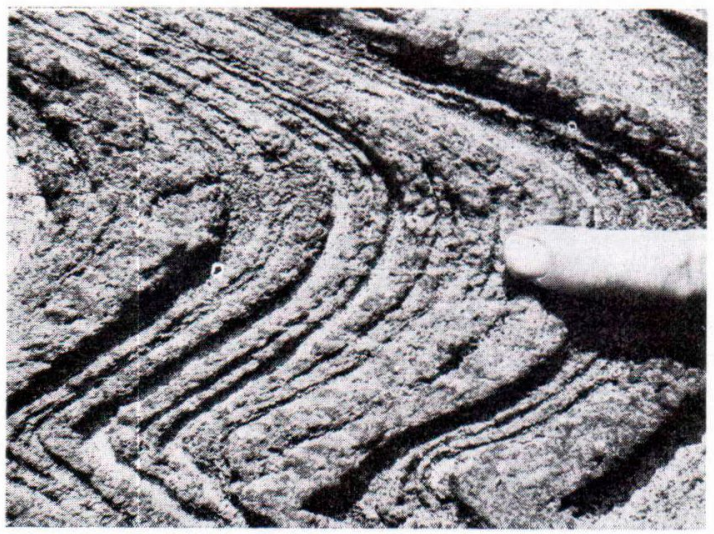

FIG. 20. $\mathrm{F}_{2}$-fold in thinly laminated quartzite and fine plagioclase-pyroxene granulite. Subarea A.
Minor folds are common in the supracrustal rocks northeast and east of the Morin Mass (Figs. 16 to 21). The frequency of occurrence

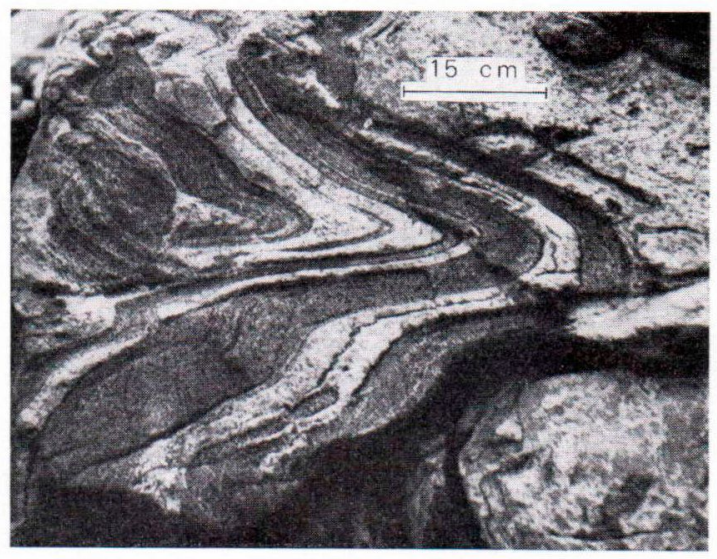

FIG. 17. $F_{2}$-fold in interlayered quartzofeldspathic and pyroxene-amphibolitic rocks. Subarea A.

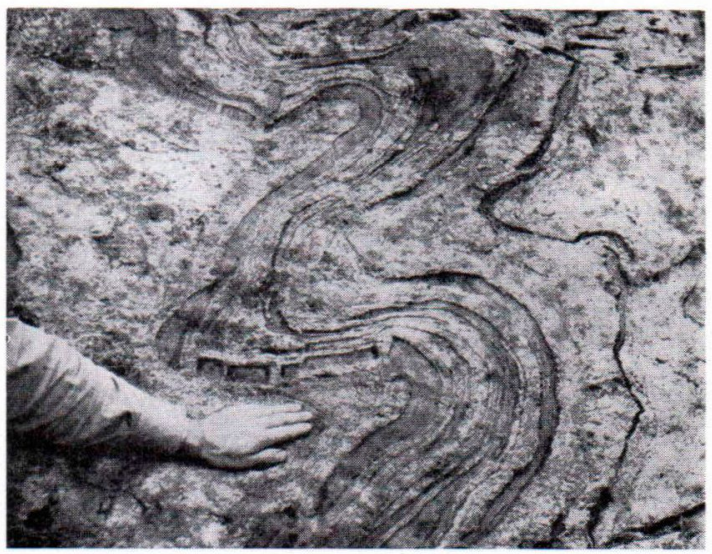

FIG. 19. $F_{2}$-folds in interlayered quartzites and amphibolites. Subarea J.

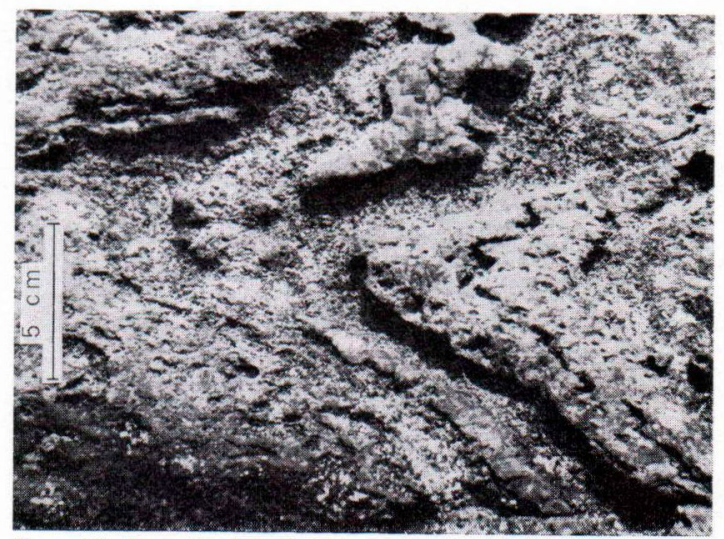

FIG. 21. Detail of $F_{2}$-fold in quartzite. Note faint axialplane foliation. Subarea K. 
of minor folds elsewhere in the area is unknown, and too few observations are available to include them in the present general description.

Generally, the folds are disharmonic, nearly isoclinal, and if undisturbed by later movements, recumbent to gently inclined. They occur in all sizes, the observations only being limited by the size of the outcrops. Amplitude to wavelength ratios vary from fold to fold, and from layer to layer within a fold. Flank to hinge orthogonalthickness ratios range from $1: 1$ to $1: 3$. The determination of these quantities is usually uncertain: a folded layer may be visible in the hinge zone, but is pinched out in the flanks and cannot be traced from closure to closure. Relict folds with sheared-off flanks and well-preserved folds of otherwise similar geometrical properties may occur in the same outcrop.

Some of the details of fold geometry can be correlated with the composition of the rocks. For example, thin amphibolitic layers, if alternating with thick quartzofeldspathic layers, are very thin or absent in the flanks of folds, and very thick in the smoothly rounded hinges. Thin quartzite beds interlayered with crystalline limestone are commonly torn apart and form irregular angular fragments, which can only be seen to line up in fold shapes in very large exposures.

Besides the various shapes that occur side by side, a general change in the »degree of preservation" and orientation of the folds is present in the area and will be discussed in the description of the subareas.

The folded planes are defined by compositional layering and $S_{1}$, and the axial planes and axes of the folds are parallel or subparallel to $\mathrm{S}_{2}$ and $\mathrm{L}_{2}$ respectively. These folds are referred to as $\mathrm{F}_{2}$ in the remaining part of this paper.

Folds very different from and younger than $\mathrm{F}_{2}$ occur in the area, but penetrative fabric elements younger than $S_{2}$ have not been observed.

\section{Fabric elements in plutonic rocks}

A variety of primary and secondary planar fabric elements, to be called $\mathrm{S}_{i}$ and $\mathrm{S}_{2}$ respectively, can be distinguished in the plutonic rocks. Measurements of their orientations are more difficult to make than in the supracrustal rocks because the plutonites rarely break along their s-planes. Fortunately, primary fabric elements in the plutonites are much more consistent in attitude than those in the supracrustal rocks; thus, the statistical value of one measurement of the former is equivalent to a large number of the latter.

Intersecting s-planes have rarely been observed in the plutonites: observations on polished blocks and microscopic fabric analysis might reveal such phenomena.

In the coarse-grained anorthosite of the Main Body, the most common $\mathrm{S}_{i}$-plane is that defined by the alignment of (010) faces of plagioclase laths (Fig. 3), which is invariably parallel to the vague tabular concentrations of mafic minerals described before. This plane is considered to represent a magmatic depositional fabric; it is penetrative at the scale of a large outcrop, but rarely at the scale of a handspecimen.

In the jotunites and mangerites, the common strongly preferred planar orientation of angular to subangular tabular xenoliths can hardly be interpreted as anything but a plane related to magmatic flow (cf. Schrijver, 1968). However, the foliation parallel to this plane, in the plutonic rocks themselves, is commonly formed by parallel arrangement of small aggregates of recrystallized minerals and has all the aspects of a synkinematic metamorphic foliation. This seems explicable only if it is assumed that the geometry of synkinematic recrystallization was controlled, to some extent, by planes generated in the magmatic stage. Consequently, in Plate 1, all splanes in the jotunites and mangerites are indicated by the symbol for $S_{i}$.

A few types of secondary planar fabric elements are present in the anorthosite. Like thei 
scalar textural properties, their preferred orientations grade into each other and into that of the primary fabric (see Pl. 1: from Eastern Lobe to center of Main Body).

$S_{\dot{2}}$ is best developed in the southern part of the Lobe. Here the plagioclase fabric is fine- to medium-grained (one to two millimeters), saccharoidal eugranoblastic, with some large relicts of mauve plagioclase (see also: Osborne, 1949). The $S_{2}$-plane is defined by long thin aggregates of dark minerals (pyroxenes and minor hornblende and biotite); the rock could be called an anorthositic gneiss. The long axes of the subrounded to diamond-shaped plagioclase relicts lie in this plane (Fig. 23). Like the granoblastic matrix they are not or only slightly strained.

Further northward, in the northern part of the Lobe, plagioclase relicts are more abundant, less regular in shape and show evidence of considerable strain. All gradations are present from unstrained diamond-shaped relicts to strongly strained porphyroclasts, and from a saccharoidal eugranoblastic matrix to an interlobate hemigranoblastic one (for this nomenclature, see Berthelsen, 1960, p. 24). Here, in the northern part of the Lobe, it is only along the contact of anorthosite and supracrustal rocks that the texture is perfectly saccharoidal eugranoblastic and gneissic. Elsewhere, the dark minerals and

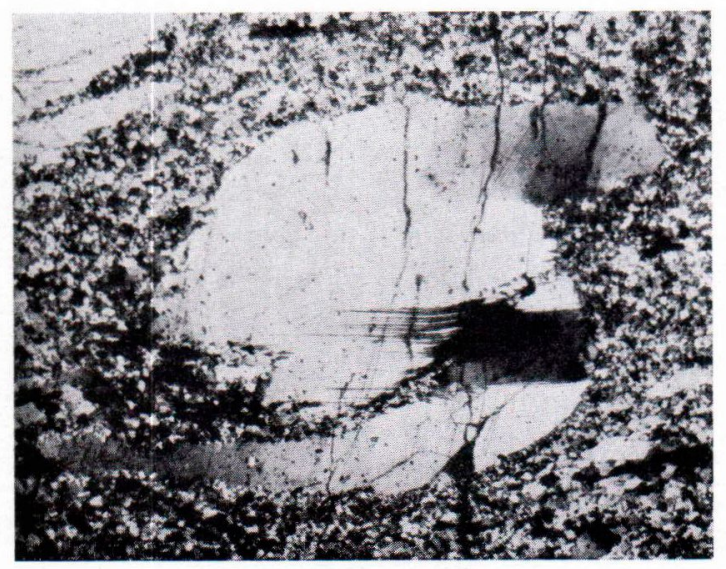

FIG. 22. $S$-shaped plagioclase porphyroclast in cataclastic anorthosite. $12 \mathrm{x}$. the porphyroclasts are not as well aligned as in the southern part of the Lobe.

Close to and across the junction of the Lobe and the Main Body, evidence of strain and incomplete recrystallization is even more pronounced. Porphyroclastic-, augen-, flaser-, and blastomylonitic-structures (Figs. 22, 23) suggest a large fault zone in the Mass. Evidence of brittle fracture is absent, and it seems that ductile failure under plutonic conditions has occurred.

Similar, but very narrow, blastomylonitic shear zones, one centimeter to one meter wide, are also present in the Main Body and its surrounding plutonites, where they cut through the $\mathrm{S}_{i}$-planes. These shear zones are rarely penetrative, even at the scale of very large outcrops; systematic measurements have not been made, and they are not recorded on Plate 1.

A mineral lineation $\left(\mathrm{L}_{2}^{\prime}\right)$ is commonly present on the foliation planes of the mangeritic augen gneisses and the gneissic jotunites.

In the Main Body, lineation has not been observed, except in some narrow anorthositic and quartzofeldspathic shear zones.

In the Eastern Lobe, the long thin aggregates of dark minerals that define $\mathrm{S}_{2}$ are, in fact, strongly elongate ellipsoids of which the long axes are aligned and define a lineation $\left(\mathrm{L}_{2}\right)$. The

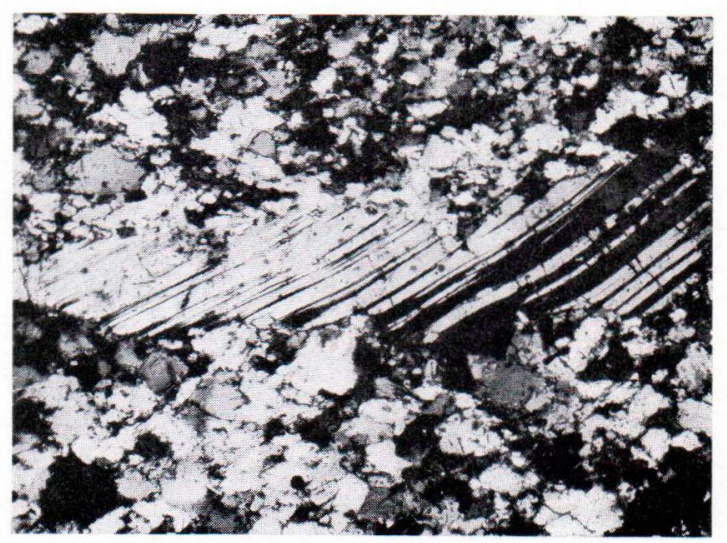

Frg. 23. Twin lamellae in plagioclase porphyroclast making acute angle with foliation $\left(\mathrm{S}_{2}^{\prime}\right)$ in anorthosite. $30 \mathrm{x}$. 
large plagioclase relicts do not seem to take part in this alignment. Thus, the intensity of the lineation shows a gradual change over the Eastern Lobe, similar to that of the foliation: intense along the rim and throughout the southern part of the Lobe, but poorly developed in its northern part.

Minor folds are extremely rare in the plutonites. They have not been observed in the jotunites and mangerites. However, in the anorthosite, a few minor folds, somewhat similar to $\mathrm{F}_{2}$-folds in the supracrustal rocks, are present near the eastern (Figs. 32, 33) and western margins of the Lobe.

Two features of interest in a consideration of the deformation of the anorthosite should be mentioned here:

Firstly, as noted by Osborne (1949), the (010) planes of relict plagioclase grains, whether diamond-shaped or porphyroclastic, make an angle with the $S_{2}$-planes (Fig. 23). A correlation between this angle and the type and intensity of deformation is suggested by Osborne's work (op. cit.).

Secondly, small noritic bodies have been observed in the anorthosite of the Eastern Lobe, which are strongly reminiscent of flattened equivalents of the spherical subophitic norite bodies described on p. 173 (see Figs. $24 a, b$ ). It is tempting to compare the shapes of the Main Mass and the Eastern Lobe with those of the spherical and flattened noritic bodies respectively.

\section{Structural compilation}

Large, natural structural units were outlined by us, in the field, after most of the structural compilation was completed. The division into subareas could have been far more effective if there had been at least a rough idea of the scale and geometry of major structures. As such was not the case in most previous work we were forced to work the other way around: a rather

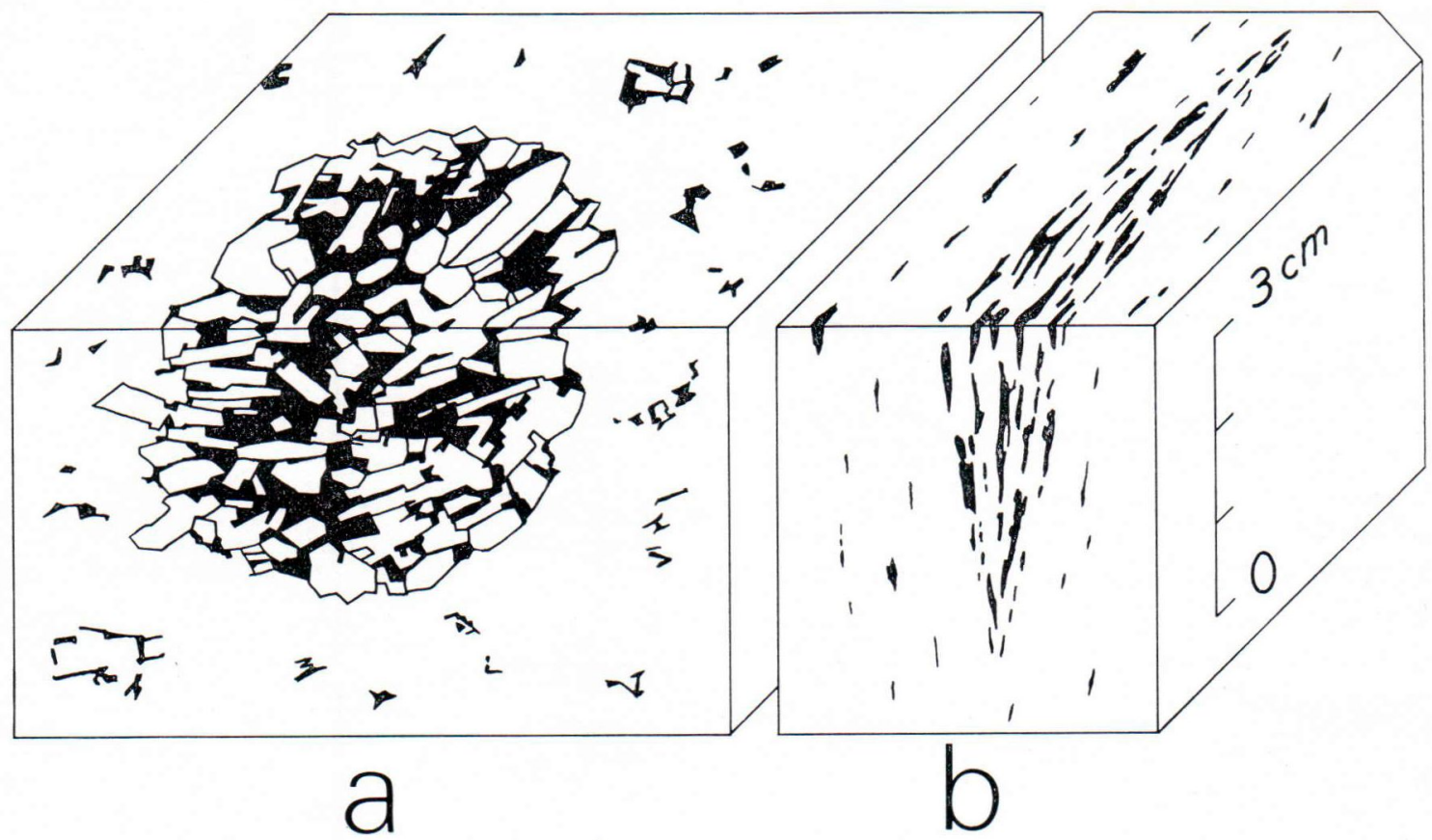

FIG. 24. Small noritic body in anorthosite. (a) in Main Body; (b) in Eastern Lobe. 
artificial division of the area into subareas was made, and synoptic diagrams were prepared in order to outline where additional field work most likely would be succesful.

\section{Structural compilation map}

The structural compilation map (Pl. 2) covers an area of approximately 2400 square kilometers northeast of the Morin Mass and 800 square kilometers of the Mass itself. The major part of the anorthosite (Main Body) has not been included in Plate 2 because the number of measured elements is insufficient for a statistical treatment.

Very few workers have published information on the geometry of minor or major folds or have distinguished between different types and generations of fabric elements. Therefore, to make a comparison possible of the structure recorded by all workers concerned, only planar and linear elements have been distinguished in the compilation, irrespective of their relative ages.

There are large differences in the density of recorded lineations over the area; consequently there are three types of synoptic diagrams in Plate 2:

(1) Contoured foliation diagrams in which each of a small number of lineations is indicated separately.

$(2,3)$ Contoured foliation diagrams accompanied by separate contoured lineation diagrams. This type of representation is necessary where plotting of the numerous individual lineations would clutter the diagram.

The subdivision of the area shown in Plate 2 into seventeen subareas ( $A$ to $Q$ ) ranging in size from 80 to 550 square kilometers, is based on rather weak and subjective criteria:

(1) Girdles or point maxima formed by poles to foliation planes.

(2) Point maxima or girdles (partial) formed by lineations.
(3) Where subareas determined by trial and error according to criteria (1) and (2), are approximately bounded by lithological boundaries, the latter have been used as structural boundaries as well.

Interesting and well-established aspects of the change of fabric from place to place are:

(1) The continuity of change of subarea fabrics within and without the Lobe.

(2) The parallelism and the gradual congruent curvature of the boundary of the Eastern Lobe and the $\pi$-axes.

(3) The gradual change of the lineation pattern from a point maximum in subarea $A$ to a partial girdle in subarea D, accompanied by the opposite change in the foliation pattern.

Having demonstrated these facts on the macroscopic scale, we shall discuss the results of our investigations concerning the relations between the synoptic diagrams of Plate 2 and the actual structures in the subareas.

\section{Subareas A to D}

Subarea $A$. Minor recumbent, nearly isoclinal folds $\left(\mathrm{F}_{2}\right)$ are common; the orientations of their axial planes and axes are plotted in Figure 25. Well- layered meta-sedimentary rocks are abun-

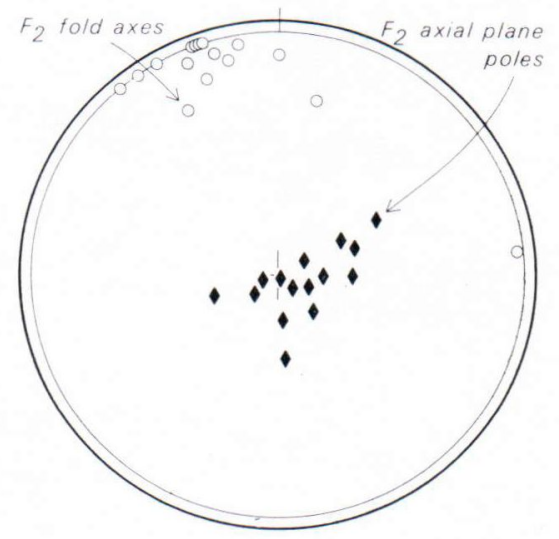

FIG. 25. Equal-area projection of $F_{2}$ fabric elements. Subarea A. (in this and the following equal-area projections, the lower hemisphere is used) 
dant and bedding foliation is well developed. $\mathrm{S}_{2}$ is poorly developed and has only been observed in the hinge zones of the folds, where it is parallel to the axial planes.

The existence of recumbent folds larger than outcrop size is suggested by the presence of narrow zones (approximately one kilometer wide) of steeply dipping bedding and $\mathrm{S}_{1}$-planes, and wider zones of subhorizontal bedding and s-planes. Strict proof for these large folds is absent, as the mapping has not been done in sufficient detail to follow marker horizons. Also, the large-scale structure around a body of leuconorite is considerably more complicated than that of the $\mathrm{F}_{2}$-folds.

Nevertheless, it is clear that the major features of the diagrams of foliation and lineation in subarea A can be ascribed to fabric elements $\left(\mathrm{S}_{2}, \mathrm{~L}_{2}\right)$ associated with $\mathrm{F}_{2}$-folds.

An interesting aspect of the orientations of the axial planes of the $\mathrm{F}_{2}$-folds (Fig. 25) is the distribution of their poles along a partial girdle coinciding with the girdle in the synoptic foliation diagram (Plate 2). It will be shown that this is most likely due to gentle coaxial refolding. Accepting this for the moment, we shall call these coaxial refolds $F_{3}$.

Subarea $B$. Well-preserved minor $\mathrm{F}_{2}$-folds are rare. Figure 26 is an equal-area projection of an oriented handspecimen of such a minor fold, measured with a contact goniometer. Relicts of recumbent folds with sheared-off flanks ("arrow heads») are common. In the present subarea, $\mathrm{S}_{2}$ is better developed than in subarea $A$; it is formed by parallelism of aggregates of grains and thin, discontinuous gneissic laminae. Layering older than $\mathrm{S}_{2}$ is generally obliterated by a pervasive recrystallization and incipient segregation parallel to $S_{2}$, thus explaining the point maximum in the synoptic foliation diagram in Plate 2.

The rather abrupt change from an incipient axial-plane foliation in subarea $A$ to a pervasive foliation in the present subarea is not purely a

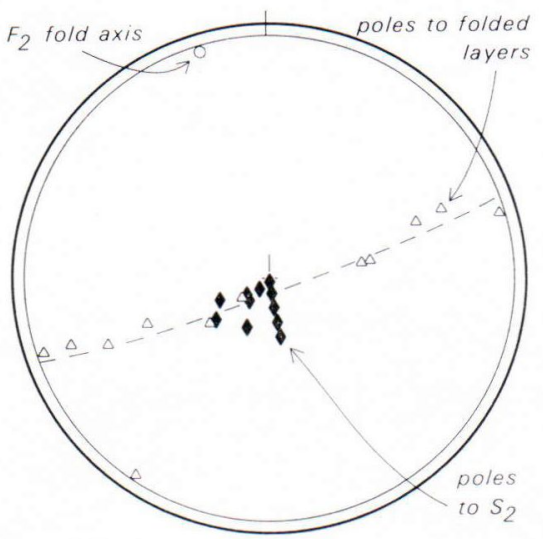

FIG. 26. Equal-area projection of poles to layering $\left(\mathrm{S}_{1}\right)$ and axial-plane foliation $\left(\mathrm{S}_{2}\right)$ in minor $\mathrm{F}_{2}$-fold. Granulite from subarea $B$.

phenomenon of more intense deformation and recrystallization. Well-layered sequences of metasedimentary rocks consisting of beds of very different mineralogical and chemical composition are abundant in subarea $A$, whereas the present subarea is underlain mainly by vaguely layered granulites ranging in composition from quartzofeldspathic to amphibolitic.

In some small domains in subarea $B$, the structure is more complex than described above. Two types of domains can be distinguished:

(1) Very rarely, a vague compositional layering is intricately but cylindrically folded about subhorizontal southwest trending axes. No lineation parallels the SW-axes; a mineral lineation trends southeasterly but is only developed on favourably oriented s-planes. The folds may belong to a generation of folds older than the common $\mathrm{F}_{2}$-folds.

(2) Not as rare, but certainly not common, are domains where the lineation varies greatly in trend and slightly in plunge, whereas the dominant foliation remains relatively constant and gently inclined. Widely divergent lineations and fold axes are present on adjacent foliation planes, although the lineation on anyone plane remains fairly constant, i.e. mesoscopically folded lineations are absent. In a few of these domains a large number of measurements of foliation and 


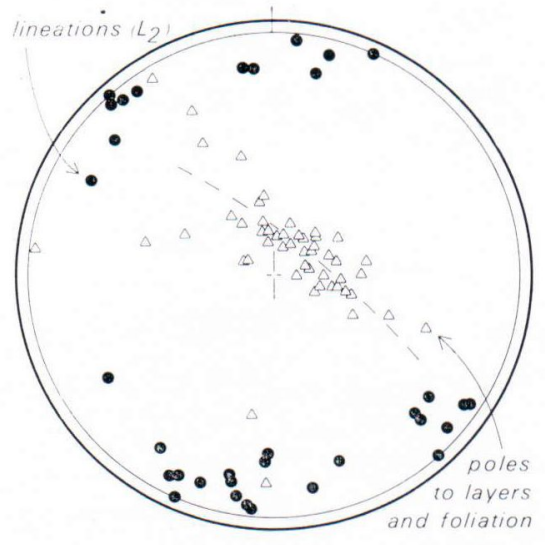

FIG. 27. Equal-area projection showing large dispersion of lineation in small domain (subhorizontal outcrop of $800 \times 20$ meters). Mainly quartzitic rocks. Subarea B.

lineation was made. The results are similar to those shown in Figure 27: a large dispersion of lineations along a subhorizontal girdle and a moderate dispersion of poles to foliation planes along a partial girdle. The poles to such partial foliation girdles plunge slightly NE or SW (in Fig. 27 the pole plunges $12^{\circ} \mathrm{SSW}$ ).

The inclusion of these small domains is the main reason for the change in lineation pattern from subarea $A$ to $B$, from a well-defined point maximum to a small partial girdle in the horizontal plane.

Subarea C. A gradual change in the fabric of the rocks occurs between subareas $\mathrm{B}$ and $\mathrm{C}$. The properties in which the change is most evident are grain size and the intensity of $S_{2}$. In subarea $\mathrm{B}$, the common leucocratic rocks (color index smaller than 30) are fine grained and $S_{2}$ is developed partly as an incipient segregation of felsic and mafic minerals. In subarea $\mathrm{C}$ however, the rocks are medium grained and $S_{2}$ is extremely well developed as a truly gneissic layering of alternating hololeucocratic layers and layers containing mafic minerals. The layers range in thickness from one millimeter to several centimeters; the rocks are, in fact, migmatites consisting of regularly alternating hololeucocratic mobilisates (potassium feldspar and quartz) and restites (plagioclase and dark minerals). A change in mineral paragenesis accompanies these changes in fabric. In subareas A and B, orthopyroxene is a common mineral in many assemblages, with or without quartz. In subareas $\mathrm{C}$ and $\mathrm{D}$, orthopyroxene is absent from common quartz-bearing assemblages.

The minor folds are similar to those in subarea $B$ : relicts of recumbent to gently inclined $\mathrm{F}_{2}$ folds are most common and occur throughout the area. The orientations of their axial planes and fold axes are plotted in Figure 28.

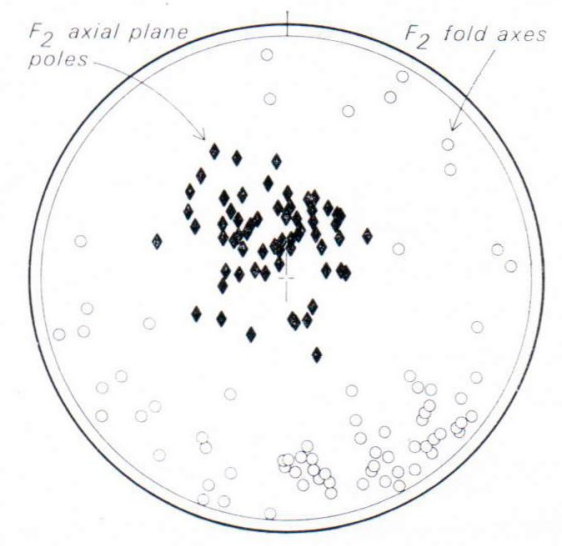

FIG. 28. Equal-area projection of $\mathrm{F}_{2}$ fabric elements. Subarea C.

Extreme flattening in a horizontal plane is suggested by the occurrence of $»$ pseudo-crossbedding» as illustrated in Figure 29, in which the preservation of the hinge of an isoclinal fold shows the tectonic origin of this phenomenon.

In the absence of rocks such as quartzite and crystalline limestone, which are rare in this subarea, the distinction between $S_{1}$ and $S_{2}$ becomes more uncertain with better development of $\mathrm{S}_{2}$. Therefore, it is mostly by comparison with subareas $A$ and $B$ that we conclude that $S_{1}$ is recumbently folded and that $S_{2}$ is the axial-plane foliation.

Recrystallization and metamorphic differentiation along planes parallel to the axial planes may 


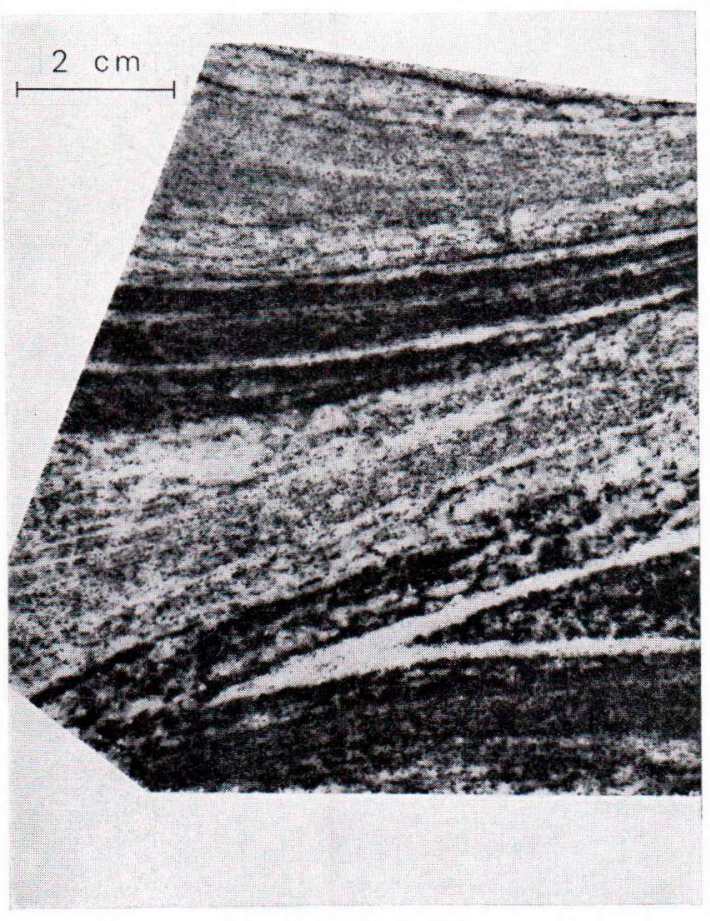

FIG. 29. Relict $F_{2}$-fold: pseudo-crossbedding and arrowhead. Subarea C.

obliterate the hinge zones of the folds, or even erase any trace of folding by irregular dispersion of the hololeucocratic component. Locally, in such strongly migmatized rocks, foliation and lineation are erased, and the fabric is practically isotropic. Clearly, migmatization outlasted penetrative deformation.

The large dispersion of lineations and fold axes in a subhorizontal plane, which was an exceptional feature in subarea $\mathrm{B}$, is general in subarea C. Many small domains (single outcrops!) show a dispersion similar to the dispersion in the entire subarea.

Gently curving folds with steep axial planes and very small amplitude to wavelength ratios occur in many parts of subarea C. Their curvature is sufficiently strong to allow measurements of axes and axial planes in the northeastern part of the subarea only. Folding of the $\mathrm{F}_{2}$-folds has been observed in a few favourable outcrops where hinges of both fold types are present. In those outcrops and elsewhere, the common lineation $\left(\mathrm{L}_{2}\right)$ and foliation $\left(\mathrm{S}_{2}\right)$ are gently folded. In contrast to the $\mathrm{F}_{2}$-folds, the present folds do not show an axial lineation nor an axial-plane foliation. The orientations of their axes and axial planes are plotted in Figure 30. It should be noted that their curvature is much too small to account for the type and amount of dispersion of $\mathrm{L}_{2}$.

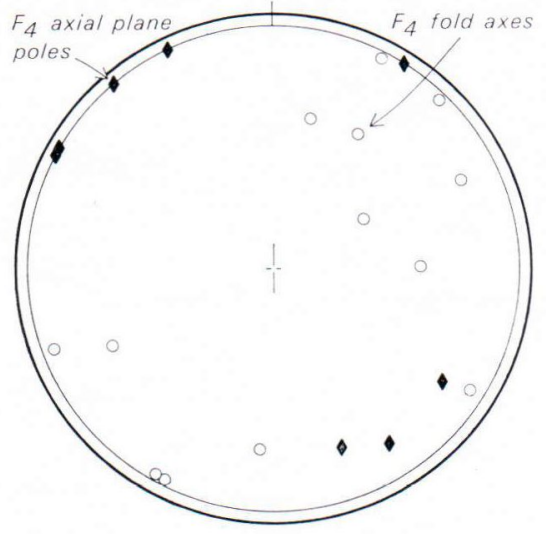

FIG. 30. Equal-area projection of $\mathrm{F}_{4}$ fabric elements. Subarea C.

One exposure has been observed where a tight fold has been folded by gently inclined folds. Figure 31 shows the mesoscopic evidence on which we base our conclusion that a generation of folds older than $F_{2}$ must be present in subarea $\mathrm{C}$.

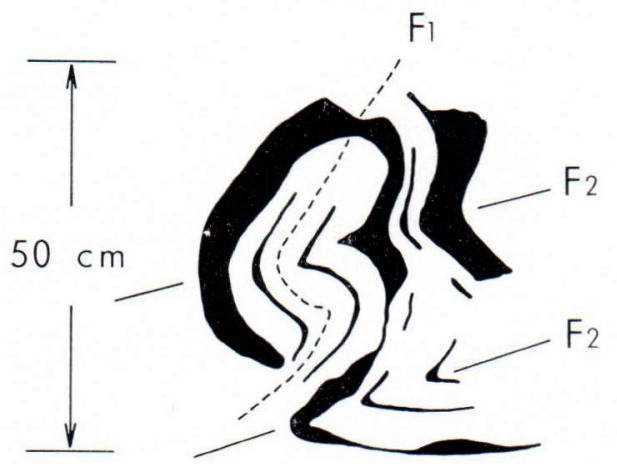

FIG. 31. Superposition of $F_{2}$-folds on $F_{1}$. Subarea $C$, near north shore Lac Patoulet, long. $73^{\circ} 32^{\prime} 15^{\prime \prime}$; lat. 46 $36^{\prime} 35^{\prime \prime}$. 
Subarea $D$ includes the major part of an area mapped by Dimroth (1963). All mesoscopic structures and fabric elements recognized in subarea $\mathrm{C}$ are also present here: (i) remnants of recumbent folds in $S_{1}$, with axial-plane foliation $\left(\mathrm{S}_{2}\right)$ and axial lineation $\left(\mathrm{L}_{2}\right)$, and (ii) gentle open folds in $\mathrm{S}_{2}$.

In an admirable structural analysis of some small parts of this subarea, Dimroth (1963) has shown that major recumbent folds, similar to the mesoscopic folds $\left(\mathrm{F}_{2}\right)$, are superposed on an older generation of major folds. These older folds are tight, trend to the west or southwest, and are overturned to the north.

The dispersion of $\mathrm{L}_{2}$ in the present subarea is even greater than in subarea C. Again, many small domains show a dispersion nearly as large as the dispersion in the entire subarea.

\section{Summary and discussion 1}

To facilitate the description of the remaining subareas, the following summary is given of the generations of folds thus far distinguished.

$F_{1}$ : A generation of major and minor folds of which very little is known. Where the axes can be reconstructed, they trend west or southwest. $F_{1}$ has not been observed in subarea $A$, but is definitely present in subarea $\mathrm{D}$. In the intervening subareas B and C, some exceptional observations fit a postulated $F_{1}$-generation of folds.

$F_{2}$ : A generation of major and minor recumbent to gently inclined, nearly isoclinal folds and associated penetrative fabric elements, which has overprinted most of the older structures, and is responsible for the major features of the synoptic diagrams shown on Plate 2.

The development of foliation parallel to $F_{2}$ axial planes $\left(\mathrm{S}_{2}\right)$ increases from subarea $A$ to $D$. Since $F_{1}$ is best preserved in subarea $D$, it is very likely that the absence of $F_{1}$-folds from subarea $A$ is an original feature and is not due to over- printing of $F_{1}$ by $F_{2}$. Consequently, $S_{1}$, well developed in subarea $A$, cannot be considered as axial-plane foliation of $F_{1}$-folds, and the term »bedding foliation» is justified.

The increasing dispersion of $\mathrm{L}_{2}$ from subarea A to $\mathrm{D}$ along a partial subhorizontal girdle suggests the intersection of $\mathrm{F}_{\mathbf{1}}$-folds by the subhorizontal $\mathrm{S}_{2}$ as a cause of the dispersion. However, this does not explain the absence of mesoscopic folds in the lineation and the presence of strongly divergent lineations on adjacent foliation planes. There seem to be two types of mechanism either or both of which could possibly account for this type of dispersion:

(1) If planes containing a lineation (strictly parallel lines) are deformed by shear along a shear plane that makes a small angle with these planes, and if the direction of movement $a$ is contained in these planes, the lineation would be deformed so that it would have different directions on adjacent surfaces (Ramsay, 1967, pp. $471-4)$. The following hypothetical sequence of events can be envisaged: After slight (?) buckling of the bedding, $\mathrm{F}_{2}$-folds developed initially by shear along gently inclined shear planes, and $\mathrm{L}_{2}$ consisted initially of a set of lines parallel to the fold axis. Further deformation took place by shear along slightly differently oriented but still gently inclined shear planes with a considerably different orientation of the $a$ and $b$ axes. If the $\mathrm{F}_{2}$-folds were nearly isoclinal before the reorientation of the shear axes, $\mathrm{L}_{2}$ would be deformed in a manner required to account for its dispersion in a plane more or less coinciding with $\mathrm{S}_{2}$.

(2) Assume that, initially, $\mathrm{L}_{2}$ and $\mathrm{F}_{2}$-fold axes had a slight dispersion. Then homogeneous flattening at right angles to $\mathrm{S}_{2}$, accompagnied by homogeneous elongation at a large angle to $\mathrm{L}_{2}$ (up to $90^{\circ}$ ) in the $\mathrm{S}_{2}$-plane, would increase the component of dispersion in $\mathrm{S}_{2}$, and decrease the vertical component of the dispersion. Either an increase in the initial amount of dispersion, or an increase in the amount of flattening from southwest to northeast would explain the type of and 
increase in dispersion from subarea A to D. In fact, both increasing initial dispersion and increasing flattening may occur in that direction as (i) early $\mathrm{F}_{1}$-folds are absent in subarea $\mathrm{A}$, and are present in $\mathrm{D}$, and (ii) evidence of flattening is more conspicuous and general in subarea D than in subarea A.

It should be noted that both continuing shear along the same set of shear planes, and superimposed flattening in a plane coinciding with those planes could be the cause of the formation as well as the disruption of the $F_{2}$-folds. Disrupted (»relict») folds could thus retain geometrical properties similar to those of the nondisrupted (»well- preserved») folds, as described before.

Besides the change in dispersion, the mean, or rather, modal orientation of $\mathrm{L}_{2}$ shows a shift from north-northwest in subarea $A$ to eastsoutheast in subarea $\mathrm{D}$. The values of the modal orientation of $L_{2}$ are given in Table 6 . The discontinuities in this shift are mainly due to the subdivision of the area.

TABLE 6.

Modal orientations of $\mathrm{L}_{2}$ in subareas $\mathrm{A}, \mathrm{B}, \mathrm{C}$, and $\mathrm{D}$

\begin{tabular}{c|c|c}
\hline \multicolumn{1}{c|}{ Subarea } & Plunge & Azimuth of trend \\
\hline A $\ldots \ldots \ldots \ldots \ldots$ & $7^{\circ}$ & 338 \\
B $\ldots \ldots \ldots \ldots \ldots$ & $0^{\circ}$ & 157 \\
C $\ldots \ldots \ldots \ldots \ldots$ & $14^{\circ}$ & 150 \\
D $\ldots \ldots \ldots \ldots \ldots$ & $16^{\circ}$ & 112
\end{tabular}

$F_{3}$ : A set of large gentle folds coaxial with $F_{2}$. The distribution of poles to $\mathrm{F}_{2}$-axial planes in a partial girdle (Fig. 25) is attributed to the $\mathrm{F}_{3}$ folds. However, this distribution can be interpreted in other ways, and the existence of $\mathrm{F}_{3}$ has not been proven in any of the subareas so far discussed.

$F_{4}$ : A generation of late, upright, very gentle major and minor folds without associated penetrative fabric elements. It accounts for local partial girdles of poles to $S_{2}$, and for slight variations in the orientation of $\mathrm{L}_{2}$.

It is clear that the subvertical maxima of poles to foliation planes in subareas B, C and D are due to the indiscriminate plotting of all planar fabric elements by one and the same symbol. The rare subvertical planes, locally shown to be, but more commonly inferred to be, $\mathrm{S}_{1}$, are masked in the contouring of the much more abundant flat foliation planes $\left(S_{2}\right.$ and $\left.S_{1}\right)$.

The descriptions of subareas A, B, C and D are far more detailed than those of the remaining subareas. This is because far more data are available from the former group of subareas than from the latter. It is with a prejudice stemming from first-hand knowledge of subareas A to $\mathrm{D}$, that we have studied the other subareas.

\section{Subareas $\mathrm{E}$ to $\mathrm{Q}$}

Subareas $E$ and $F$ are similar to B, C and D with respect to the distribution of poles to planar elements, and presumably with respect to the relations between their fabric elements and $\mathrm{F}_{2}$-folds. No further work has been done by us here.

Subarea $G$ is different from any other subarea in that it is underlain mainly by plutonic rocks. The subarea includes these rocks and a one to two kilometers wide belt of supracrustal rocks adjoining the complex (the Lac-Croche plutonic Complex: Schrijver, 1968).

The regional foliation is deflected around the complex, and the foliation in the complex is parallel to mappable lithological layering in the complex. Layering and foliation define a concordant rock-body of intricate basin-shape, steepening towards its center into an inverted cone.

The complex is tectonically deformed and recrystallized, together with the surrounding supracrustal rocks, as shown by the parallelism 
of mineral lineations in the plutonic rocks and those in the supracrustal rocks. Since the lineations in the supracrustal rocks are parallel to $\mathrm{F}_{2}$-fold axes, it is clear that the plutonic rocks were deformed simultaneously with the formation of $\mathrm{F}_{2}$-folds in the supracrustal rocks. Minor folds are very rare in the plutonic rocks owing to the virtual absence of mesoscopic layering.

The ill-defined partial girdle (?) in the synoptic foliation diagram can be attributed to the dominance of north-northwest striking foliation planes, but it is certainly not a reflection of an overall cylindrical shape of the complex.

Subareas $H$ and I. Minor folds have rarely been observed, despite extensive field work by one of us (KS). Nevertheless, the presence of a phase of deformation contemporaneous with $\mathrm{F}_{2}$ is indicated by the preferred orientation of lineations and the attitude of $\pi$-axes.

Subarea $\mathrm{H}$ is very poorly exposed, and it is questionable whether detailed field work will reveal sufficient information to explain the aberrant poorly defined girdle (?) shown in Plate 2.

In subarea $I$, the girdle to poles of planar elements $\left(\mathrm{S}_{1}\right)$ is tentatively attributed to overturned, tight folds $\left(\mathrm{F}_{2}\right)$ with axial planes dipping to the southwest at angles of approximately forty degrees. These folds are presumably larger than outcrop size: detailed mapping is required here to trace out macroscopic folds and test this hypothesis.

Subareas $J, K$ and $L$ form a zone adjacent to the eastern boundary of the Lobe of the Morin Anorthosite. They are somewhat similar to subarea $A$, at least with respect to the orientation of the $\pi$-girdles. Our field work in these subareas consists mainly of a few traverses along scarps oriented at right angles to the $\pi$-axes: the orientations of the numerous minor folds in $S_{1}$ fit the main features of the synoptic diagrams.

The folds are recumbent in subareas $\mathrm{J}$ and $\mathrm{K}$, and in the northern part of subarea L (Figs. 16,

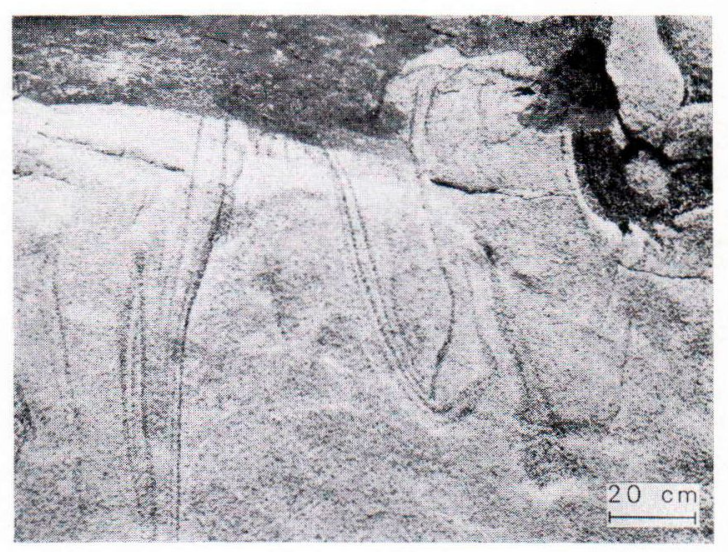

FIG. 32. Isoclinal folds in anorthosite. Subarea J.

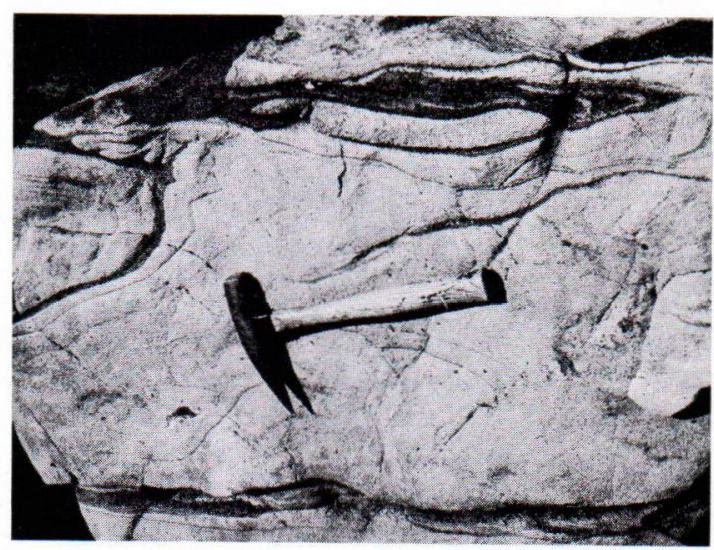

FIG. 33. Isoclinal folds in anorthosite and mafic stringers. Subarea J.

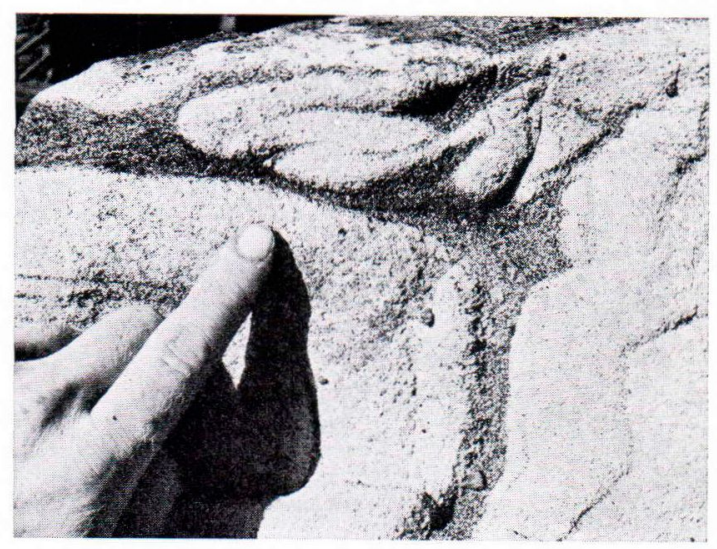

FIG. 34. Detail of Figure 33: small folds of anorthosite in mafic stringer. 


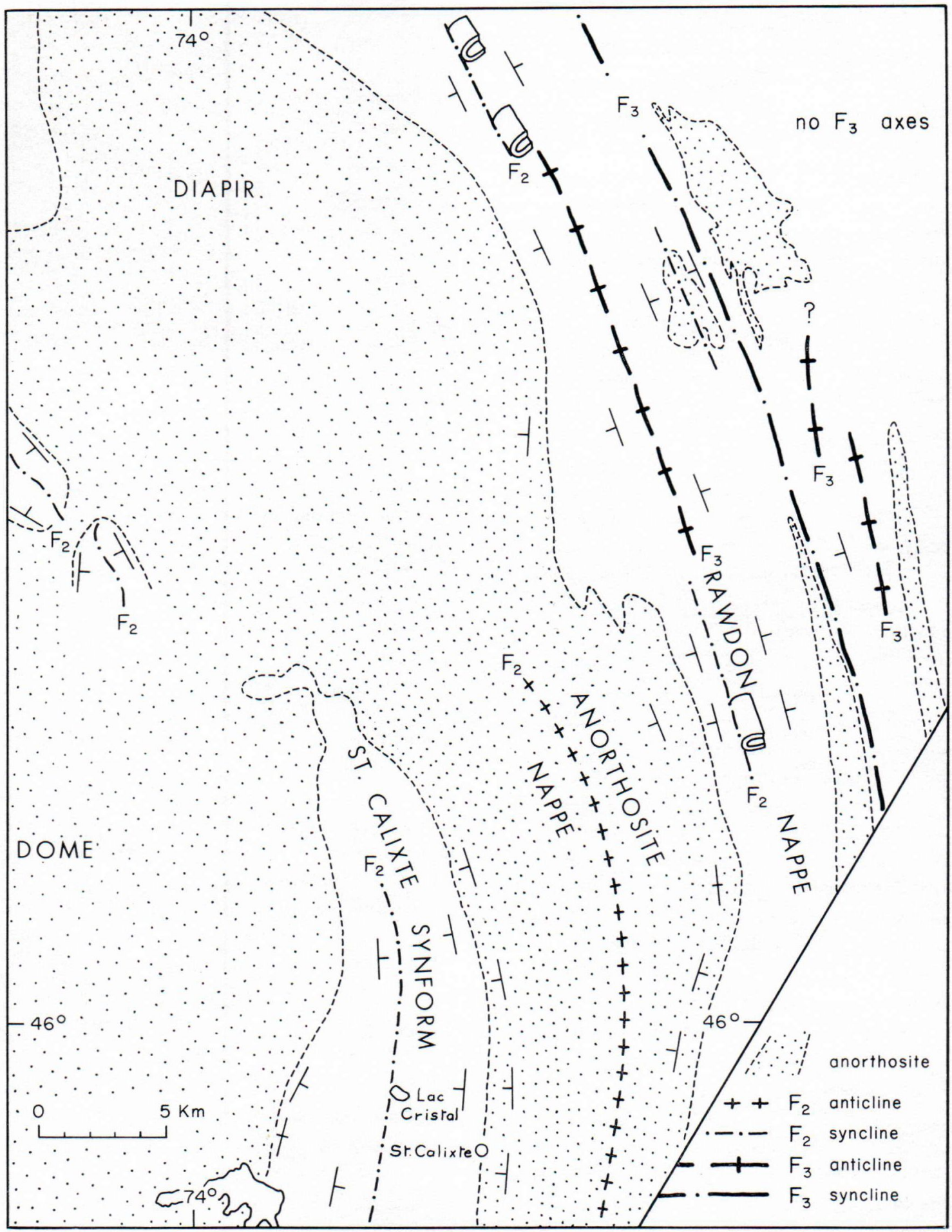

FIG. 35. Structural map of the eastern part of the Morin Mass. 
19, 21), but strongly inclined in some places in the southern part of subarea L. They have an axial lineation, and in their hinges, an axial-plane foliation by preferred form-orientation of quartz lenticles; undoubtedly, they belong to the $\mathrm{F}_{2}$ generation of folds. As indicated in Figure 35, the hinge of one large recumbent fold has been traced for forty kilometers, from east of Rawdon till the northern part of subarea J; Figure 16 shows a cross section of this hinge.

In subarea $\mathrm{J}$, isoclinal folds in medium-grained granoblastic anorthosite have been observed in a few clean water-washed blocks on a lake shore, at the foot of a talus slope. The folds are outlined by thin mafic stringers (Figs. 32, 33, 34); small folds of anorthosite in one of those stringers clearly illustrate the once ductile behaviour of the anorthosite (Fig. 34). Since the foliations and lineations in the anorthosite have orientations similar to those in the supracrustal rocks of subarea $J$, it is likely that the folds in the anorthosite are $\mathrm{F}_{2}$-folds.

The presence of large, generally gentle folds coaxial with $\mathrm{F}_{2}$ in subareas $\mathrm{J}, \mathrm{K}$ and $\mathrm{L}$ is revealed by the presence of zones of predominantly eastdipping and zones of predominantly west-dipping s-planes. As shown in Figure 35, the hinge lines of these folds are relatively continuous and closely spaced near the boundary of the Morin Mass, but discontinuous and widely spaced away from the Mass. Presumably, their axial planes are steeply inclined or vertical, but no evidence is present to substantiate this. The degree and sense of asymmetry of the $\mathrm{F}_{2}$-folds ("sens de déversementy) cannot be determined from the diagrams because of the refolds.

A few minor folds with subhorizontal easttrending axes have been observed in subarea J, close to the hinge of one of the large folds described above. These minor folds have strongly inclined axial planes, and they clearly deform the lineation (Fig. 36). They are in all respects similar to the folds described as $\mathrm{F}_{4}$ in subareas $\mathrm{C}$ and $\mathrm{D}$.

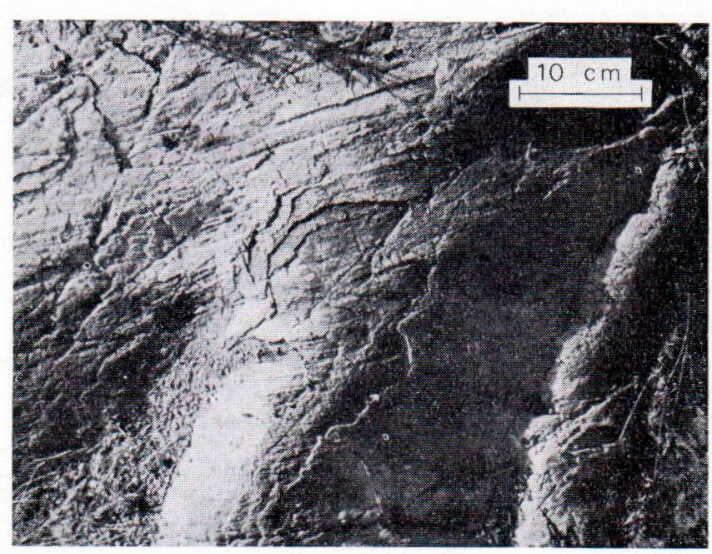

FIG. 36. Lineation $\left(\mathrm{L}_{2}\right)$ folded by $\mathrm{F}_{4}$. Subarea J.

The relative ages of these two types of folds the large folds coaxial with $F_{2}$, and the minor folds that deform $\mathrm{L}_{2}$ - are unknown, but it is clear that they do not belong to the same phase of deformation. We tentatively call them $\mathrm{F}_{3}$ and $\mathrm{F}_{4}$ respectively.

As stated above, in the southern part of subarea $\mathrm{L}$ there are minor folds which are similar to $F_{2}$-folds in most respects, but which have moderately to strongly inclined (up to $60^{\circ}$ ) axial planes. They are well exposed near the village of Rawdon (in the rapids at the dam and in the Chute Masson, at the south end of Rawdon Lake), one kilometer east of the boundary of the Morin Mass. These folds are attributed to tilting of $\mathrm{F}_{2}$-folds by $\mathrm{F}_{3}$-folds, where the latter are relatively tight. However, it is doubtful whether the curious symmetry shown by the $\pi$-girdle of subarea $L$ can be explained in this way. Unfortunately, we do not know the true symmetry of the girdle: during our field work in the area, it seemed that many more subhorizontal s-planes are present than are recorded on the published map.

Subarea $M$ is underlain entirely by wellfoliated and lineated, medium- to fine-grained, porphyroclastic to eugranoblastic anorthosite and leuconorite. Neither $S_{i}$-planes nor minor folds have been observed, and the foliation is of the $S_{2}$-type. 
The subarea is exceptionally homogeneous with respect to the foliation: small domains of, say, ten square kilometers, show essentially the same symmetrical array of foliation-plane poles as the entire subarea.

The small partial girdle in the diagram (Pl. 2) can be interpreted in a number of ways: (i) a set of non-folded planes having a common line of intersection $\left(\mathrm{L}_{2}\right)$; (ii) gentle open upright folds in a gently westward dipping homocline $\left(\mathrm{F}_{3}\right.$ ?); (iii) tight isoclinal folds with gently dipping axial planes $\left(\mathrm{F}_{2}\right.$ ?).

The last one is preferred for the following reasons: (a) Minor isoclinal folds $\left(\mathrm{F}_{2}\right.$ ?) are present in the anorthosite in subarea J. (b) The indentations in the east and west boundaries of the anorthosite and other rocks, coinciding with the boundaries of the present subarea (see Pl. 2), can be explained by slightly plunging isoclinal folds and not by gentle open folds. (c) There are steep foliation planes, although they are very rare.

If the correct alternative is chosen, there is an important corrolary: whereas bedding and bedding foliation in the supracrustal rocks were folded, and axial-plane foliation developed in $\mathrm{F}_{2}$-folds, $\mathrm{S}_{2}$ was deformed (formed?) into shapes similar to $\mathrm{F}_{2}$-folds. How similar these shapes are, is particularly well illustrated in Fig. 37, which shows the distribution of attitudes of $S_{1}$ and $S_{2}$, in a narrow zone straddling the interface between supracrustal rocks and anorthosite.

Subarea $N$ covers a part of the boundary zone between the Main Mass and the Eastern Lobe, and is underlain by anorthositic-leuconoritic rocks of a great variety in fabric: from mediumgrained eugranoblastic to porphyroclastic and coarse-grained cumulate-type textures. The subarea also includes a »tongue» of mangeritic and supracrustal rocks (northerly extension of StCalixte Synform: see Fig. 38).

The synoptic diagram is an indiscriminate plot of $\mathrm{S}_{1}, \mathrm{~S}_{2}, \mathrm{~L}_{2}, \mathrm{~S}_{1}$ and $\mathrm{L}_{2}$. All foliation-plane poles lie on a well defined girdle, but little value can

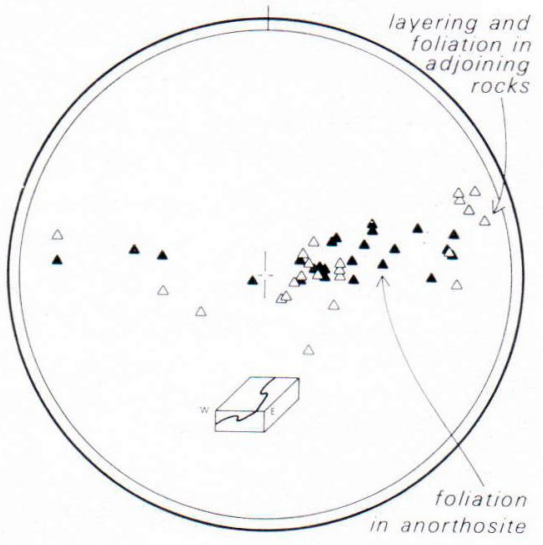

FIg. 37. Equal-area projection of planar fabric elements in 700 meters wide zone straddling anorthosite boundary in subareas J, L, and $\mathrm{M}$.

be attached to the distribution along the girdle as the distribution of measurement locations and the symmetry from domain to domain are far from uniform.

Some features of interest, that cannot be read from the diagram, are:

(a) In the anorthosite, $S_{i}$ - and $S_{2}$-planes are difficult to distinguish in the field, but the poles to all planar elements lie on the same girdle. The only difference seems to be that the average $\mathrm{S}_{1}$ is somewhat steeper and $\mathrm{S}_{i}$ dips predominantly eastward, whereas $S_{2}$ dips predominantly westward.

(b) $\mathrm{L}_{2}^{\prime}$ and $\mathrm{L}_{2}$ are parallel to each other.

Subarea $O$ is underlain mostly by porphyroclastic anorthosite, grading into eugranoblastic gneissic anorthosite toward the eastern and northeastern rim of the Lobe.

The subarea is extremely heterogeneous with respect to its foliation $\left(\mathrm{S}_{1}\right.$ and/or $\left.\mathrm{S}_{2}\right)$. Most planes represented in the synoptic diagram are from the southern part of the subarea and from the norheastern rim of the Lobe; it is mainly the poles to these planes that give rise to the girdle.

It should be noted that flat foliation planes are scarcer, and steep ones are more abundant in this subarea than in any other subarea underlain by anorthosite. 
Subarea $P$ covers a narrow zone on either side of the northwestern boundary of the Lobe, and a small area north of that zone.

In the southern part of the subarea, $S_{1}$ and $S_{2}$ have attitudes consistently eastward dipping; $\mathrm{L}_{2}$ and $\mathrm{L}_{2}$ are parallel and plunge toward the east at angles up to sixty degrees. Most relatively flat and all westward-dipping planes $\left(\mathrm{S}_{1}\right)$ are from the northern part of the subarea, where $L_{2}$ plunges to the south-southeast at angles up to thirty degrees.

A gently folded lineation, presumably $\mathrm{L}_{2}$, has been observed in the northern part of the subarea. The lineation and its containing plane (bedding?) are gently folded over a late fold axis plunging gently toward the northeast (determined stereographically). Fabric elements related to this late fold have not been observed, thus the folds have all the characteristics of the $\mathrm{F}_{4}$ folds described before. The folded lineation shows a small spread, too small to fit either a great or a small circle to it.

Subarea $Q$. The diagram contains all the structural information about this subarea.

Summary and discussion 2

The reader is referred to "Summary and discussion 1 " for a review of the four generations of folds distinguished in subareas A to D. None of these generations is homogeneously developed over the entire area covered by the compilation map (Pl. 2). Nevertheless, some aspects of the structure of the area can be summarized in terms of these fold generations.

$F_{1}$ : In the subareas adjacent or close to the anorthosite mass, no trace of $F_{1}$-folds has been observed. Their presence seems to be restricted to the subareas east and northeast of the LacCroche Complex, but much more detailed field work (stratigraphy!) is necessary to outline these old structures.
$F_{2}$ : The very gradual changes in the attitudes of mineral lineations and $\pi$-poles over the area strongly suggests one main phase of deformation, to which not only the supracrustal rocks but also the plutonites were subjected.

If this is accepted, it is clear that this phase of deformation has given rise to a great variety of structures, which would not have been attributed to a single phase if only a few small domains, far removed from each other, would have been studied.

Most changes in structure seem to be correlated, at least spatially, with the position of the anorthosite mass. The change from a statistically cylindrical fabric and well preserved recumbent folds close to the eastern boundary of the Lobe, to a non-cylindrical fabric and relict recumbent folds further east and northeast from the Lobe, has already been discussed, and is substantiated by the structure of subareas $\mathrm{J}, \mathrm{K}$ and $\mathrm{L}$.

In the area north and northwest of the Lobe (subareas I, P, Q) very little is known about minor folds, and virtually nothing about major structures. In any case well developed or well preserved minor folds have not been observed.

Such was also the case in subarea $N$, until we found by detailed field work, that its southeastern part is underlain by the northerly extension, in fact the axial culmination, of a major synform (St-Calixte Synform, see Fig. 38), which changes from north to south from a slightly inclined, strongly overturned synform, to an open one. The synform, at least in its northern part, is similar in many respects to minor $\mathrm{F}_{2}$ folds, but its flanks as well as its hinge zone are characterized by their poverty in minor fold.

$F_{3}$ : Major upright to strongly inclined folds, coaxial with $\mathrm{F}_{2}$, seem to be most clearly related to the anorthosite mass. Their occurrence is restricted to the area adjacent to the eastern boundary of the Lobe (subareas J, K, L, and probably A). Their trend is strictly parallel to this boundary and they can be traced as far 
north as the point where the Lobe turns from north-northwest to northwest.

The status of these folds as a distinct "phase» of deformation is in doubt. Generally, isoclinal recumbent folds and gentle coaxial refolds are considered to be parts of one continuous process of progressive deformation; this seems likely in the present case.

Why they are restricted to the immediate surroundings of the Lobe must remain unanswered, at present, but we will return to this question on page 202 .

$F_{4}$ : Some minor folds have been observed, a few in subarea $\mathrm{J}$, and one in subarea $\mathrm{P}$. They have in common with the $\mathrm{F}_{4}$-folds in subareas $\mathrm{C}$ and $\mathrm{D}$, the property that they deform $\mathrm{L}_{2}$ (Fig. 36). They are tentatively assigned to the same late phase of deformation.

A problem, up till now evaded, although touched upon in the description of subarea $\mathrm{M}$, is the correlation between s-planes in the supracrustal rocks and those in the plutonites. The following points have a bearing on this problem:

(a) Folding $\left(\mathrm{F}_{2}\right)$ and the development of $\mathrm{S}_{2}$; seem to be closely related: $S_{i}$ wherever it can be recognized (Main Body) is not, or only very gently folded and $S_{2}$ is not present there.

(b) Within the Lobe, minor folds have not been observed, but it is probable that $S_{2}$ is folded into relatively large isoclinal $\mathrm{F}_{2}$-type folds (see description of subarea $\mathrm{M}$ ).

(c) Along the major part of the eastern boundary of the Lobe, $\mathrm{S}_{2}$ and $\mathrm{S}_{1}$ are similarly folded (see Fig. 37), although perhaps at different scales: minor folds are rare in the anorthosite, but common in the supracrustal rocks.

(d) The only other place where a minor fold in anorthosite has been observed is at the foliated, gneissic western rim of the Lobe (outside the area covered by the compilation map).

It is suggested that $S_{i}$ developed during the phase of deformation that gave rise to $\mathrm{F}_{2}$-folds in both $\mathrm{S}_{1}$ and relatively early $\mathrm{S}_{2}$-planes. These early $\mathrm{S}_{2}$-planes would have been formed only at and near the interface of the Lobe and supracrustal rocks. Later $\mathrm{S}_{\dot{2}}$-planes developed, according to this hypothesis, within the Lobe during that same phase of deformation, their initial and later geometry being determined by major folds forming at the interface.

Thus, $\mathrm{S}_{2}$ is correlated with - i.e. it is considered to be approximately contemporaneous with $-\mathrm{S}_{2}$. The completely different orientations of these two fabric elements with respect to $\mathrm{F}_{2}$-folds can only be ascribed to differences in mechanical behaviour of the rocks involved in the deformation.

\section{Shape and evolution of major structures}

Because of its size and relative homogeneity, the Morin Mass must have affected the structural evolution of its surroundings. Therefore, this section is devoted mainly to major structures in which the anorthosite is involved.

The Morin Mass appears to consist of three major structural units: a dome, a nappe and a diapir-like unit (see Figs. 35, 39).

Firstly, the geometrical evidence for a threefold subdivision will be given, the nomenclature being based on a comparison of the inferred shapes of those structural units with large structures well known from the geological literature (Argand, 1911: Swiss Alps; Haller, 1955: East Greenland). Secondly, the consequences of this subdivision in terms of movements and the role of gravity in these movements will be considered. Finally, the problem of gravityinduced vs. gravity-controlled emplacement and deformation will be broached in a synthesis of the tectonic evolution of the entire area.

The main Body, its jotunite rim and part of the mangerite form one rather simple structural unit. From the consistency of outward-dipping $S_{i}$-planes, there remains little doubt that this unit has the general shape of a dome. The lower, major part of this dome is formed by anorthosite, 
and its shape, as shown in Figure 39, is inferred from the attitudes of $S_{i}$ and lithological contacts. In Figure 39, the top of the western part of the dome is drawn a few hundred meters above the present level of erosian, whereas the eastern part is even closer to this level. This is based upon our interpretation of the patches of jotunite, mangerite and quartzite occurring win» the Main Body (see Pl. 1) as being remnants of a cover for the following reasons:

(a) We know from field observations that the patches are open synclinal keels. As Adams' reference (1896) to these occurrences as minclusions" seems to have become engrained in the literature, it should be stressed once more, that small unambiguous xenoliths have not been found in the anorthosite; their occurrence is restricted to the jotunites and mangerites.

(b) The largest patches are connected with similar open synclines in the supracrustal rocks surrounding the Mass (Lac-Quinn Formation).

(c) Jotunite (-mangerite) layers occur between most quartzite patches and anorthosite.

The Eastern Lobe differs from the Main Body in shape, associated rocks (thin partial jotunite rim and virtual absence of mangerite), and type of deformation. Because of these differences, and its envelope of supracrustal rocks (LQF), the Lobe has been considered, up till now, as one unit. However, within the Lobe, an important gradual change in the structural pattern is present: the intensity and regularity of deformation decrease from south to north, as inferred from textures and structures in the anorthosite. Therefore, the southern and northern parts of the Lobe are treated separately below.

The southern part of the Lobe is in contact on either side with the gently westward-dipping LQF. The sequence west of the Lobe is garnetsillimanite gneiss - LQF (-anorthosite), and detailed work by one of us (JM) shows that this sequence is part of the long limb of a major overturned synform (St-Calixte Synform, see

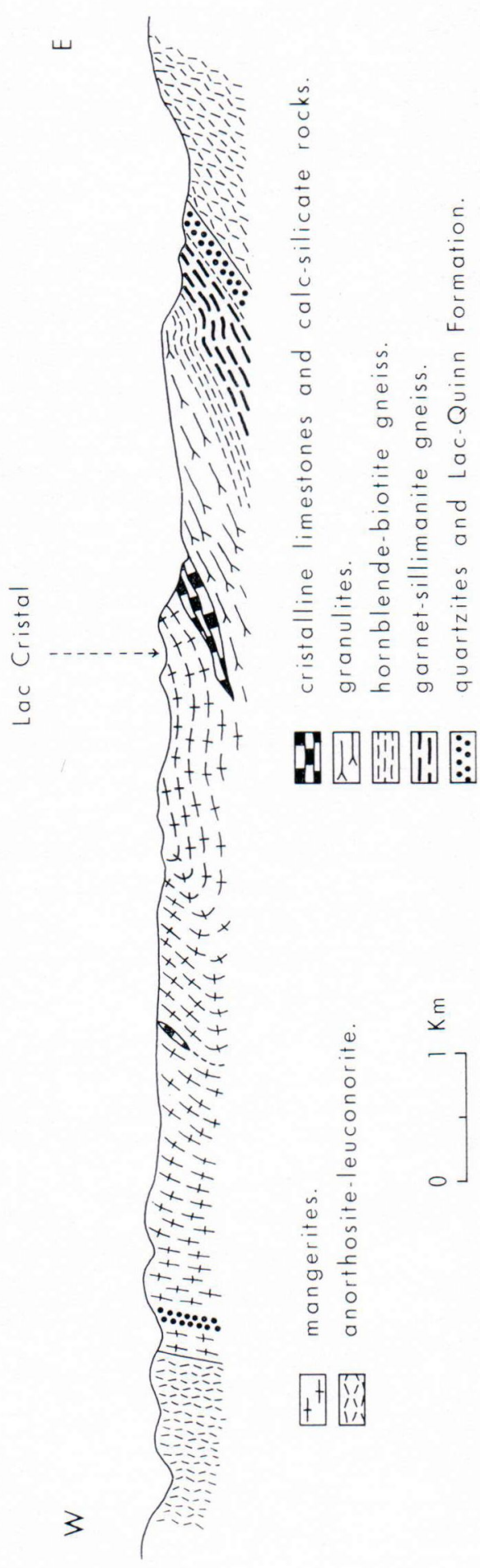

FIG. 38. Section across St-Calixte Synform. 
Figs. 35, 38). The sequence east of the Lobe is (anorthosite-) LQF - garnet-sillimanite gneiss, and participates in a major gently inclined to recumbent fold (Rawdon nappe: see Fig. 35).

Attitudes of $\mathrm{S}_{2}$-planes in anorthosite and $\mathrm{S}_{1^{-}}$planes in supracrustal rocks, in a seven-hundred meters wide zone straddling the eastern boundary of the Lobe, are plotted in Figure 37. Since there is no hinge of $\mathrm{F}_{3}$-folds in this zone, the symmetry in the diagram can be interpreted in terms of $\mathrm{F}_{2}$-folds. Thus, the array in Figure 37 suggests long west-dipping and short east-dipping limbs, equivalent to $S$-shaped folds, indicating eastward and upward closure in the supracrustal rocks as well as in the anorthosite. Mesoscopic and larger parasitic folds are, in fact, present on either side of the southern part of the Lobe, in the anorthosite as well as in other rocks (see small $Z$ shaped fold in granulite of St-Calixte Synform: Fig. 38), and corroborate an eastward closure.

The inevitable conclusion is that the southern part of the Lobe has the characteristics of a pennine-style nappe with a crystalline core (anorthosite) and a supracrustal envelope (quartzite): see Figure 39. Furthermore, it seems highly likely that the St-Calixte Synform is, in fact, a syncline, i.e. the normal stratigraphic sequence is LQF (quartzite as basal member) - garnetsillimanite gneiss.

The maximum extent of the anorthositic nappe is not known, but the presence of anorthositic-leuconoritic synforms underlain by rocks similar to the LQF suggests that at least the first few "tongues» of anorthosite east of the Lobe (P1. 1) are probably erosional relicts of $\mathrm{F}_{3^{-}}$synclines in the nappe ("synclinaux de nappe»). Further work is in progress here to locate the front of the nappe.

The northern part of the Lobe is least known: attitudes of foliation and lineation indicate a structure more complicated than either dome or nappe, but measurements are too scarce for a reliable reconstruction. Also, the structure in the surrounding rocks (especially subarea P: see
Pl. 2) is unknown, but definitely complicated, and cannot be used as a guide to the shape and structure of the anorthosite.

Similar to the relations around the dome and the nappe, the dominant foliation along the margins of the northern part of the Lobe, in the anorthosite as well as the surrounding rocks, is generally parallel to the contact, at least in strike and presumably in dip (P1. 1). Taking the attitudes of the foliation as a measure of the shape of the anorthosite body, the western and northern contacts dip inward, moderately steeply to the east ( forty degrees) and steeply to the south ( $\sim$ sixty degrees), respectively. The relative steep inward dips, taken together with the occasional abnormally steep inward plunging lineations (up to sixty degrees) suggest a diapiric shape for this part of the Lobe, very schematically indicated in Figure 39. However, the eastern contact dips outward, at least locally. Significantly, this contact is close to the northerly extension of the Rawdon nappe (see Fig. 35), and it may well be that the influence of the movement of the nappe extends northward along the boundary of the Lobe.

Proceeding from shape to evolution of the major structures, attention is drawn to the generally contrasting shapes of acid and basic plutonic bodies. It is well known that bodies consisting dominantly of acid plutonites are generally convex upward (domes, batholiths), whereas those made up of basic plutonites are generally concave upward (basins, lopoliths).

Model experiments by Ramberg (1967), in which a centrifugal force is used to imitate gravity, show that these contrasting shapes are probably related to the contrasting movements of the respective bodies in response to gravity. The relatively light, acid plutonites have a tendency to rise through the crust, whereas the denser, basic plutonites have a tendency to sink.

Although anorthosites are classed, geochemically, as basic plutonites, the negative gravity anomalies over some anorthosite masses (Thomp- 

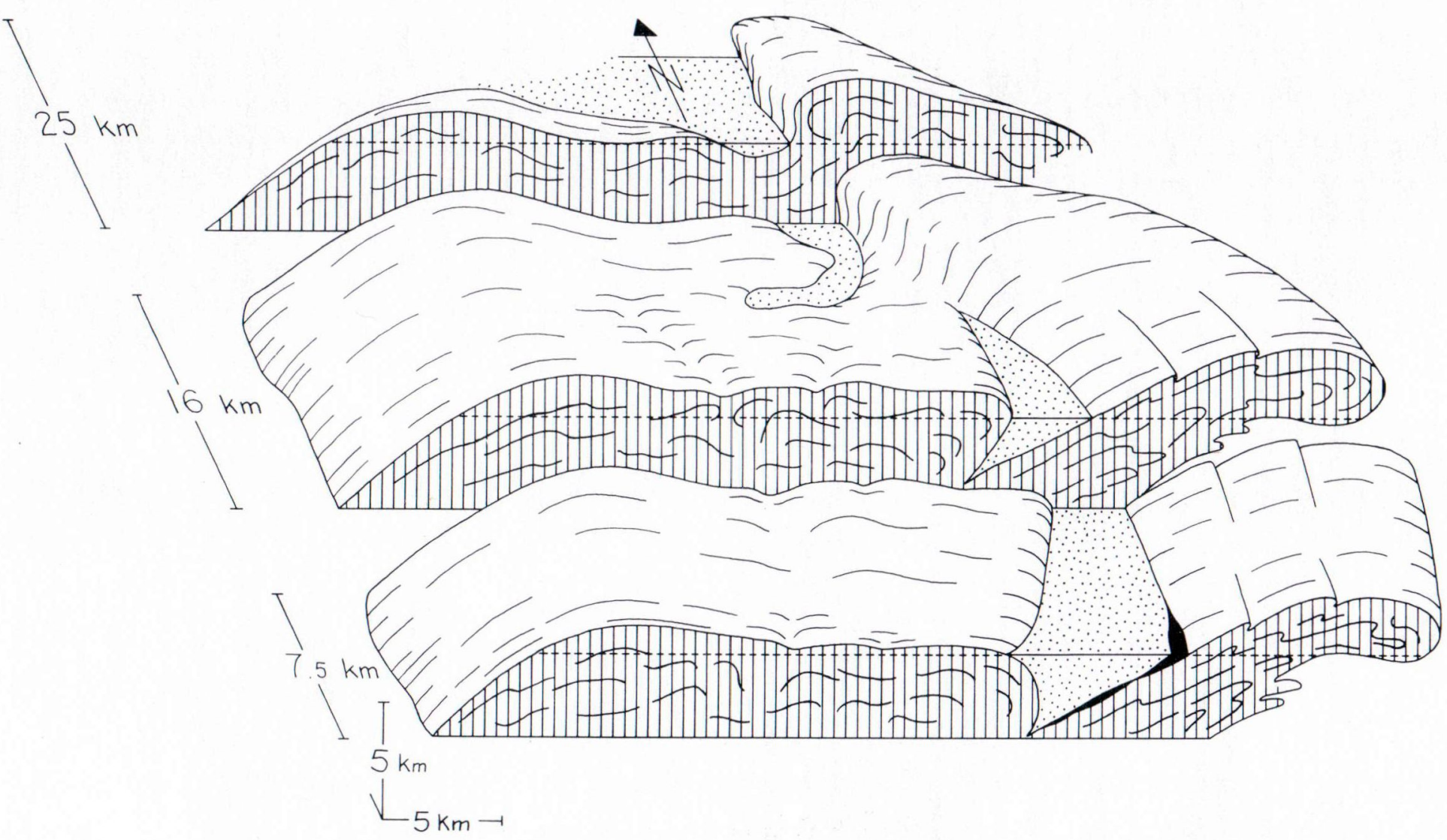

FIG. 39. Schematic block diagram of Morin Anorthosite Mass. Dotted line indicates present level of erosion. 
son and Garland, 1957: Morin Mass, LacSt-Jean Mass; Simmons, 1964: Adirondack Anorthosite) show clearly that, on the average, these masses are less dense than the surrounding rocks.

So, a first clue to the movement and final emplacement of the Morin Mass is given by a comparison of the Anorthosite dome with the top (»hat») of the mushroom-shapes generated in many of Ramberg's models. Strengthening the idea that a thorough comparison of the movements of the Mass and the scale models might be rewarding, is the striking resemblance of the Anorthosite nappe with the laterally spreading "hat», and of the Rawdon nappe with the strongly overturned rim syncline shown in some of the models (Ramberg, 1967, e.g. Fig. 35).

Whether a body will rise or sink under the influence of gravity alone, depends on a combination of factors, the most important of which are:

(a) the density contrast between the body and its surroundings,

(b) the geometrical dimensions of the body,

(c) the length of time available for the movements to take place, and

(d) the magnitude of plastico-viscous drag and the rate of its increase with increasing deformation (strain-hardening).

With respect to the Morin Mass, its dimensions are certainly sufficient for gravity to exert an important influence on any movement of the Mass with respect to its surroundings because an important density contrast exists.

Radiometric dating might set limits to the third factor, but such dates are not at hand yet.

It is about the last factor that most uncertainty exists, first and foremost because the physical state of the anorthosite and associated plutonites, at the time of initiation of the rising movement, is unknown. Anyway, the dome arrived near its present level at an advanced stage of crystallization while still containing some interstitial liquid, as shown by (i) the absence of any kind of corroded or chilled rim, (ii) the absence of xenoliths, and (iii) the presence of undeformed interstitial pyroxenes and undeformed subophitic norite bodies (Fig. 24 a). The jotunite and mangerite were, at that level and time, still largely liquid, as shown by the abundance of inclusions of supracrustal rocks, similar to those surrounding the Mass now. The relatively high viscosity of the light solid anorthosite, and the low viscosities of the denser liquid jotunite and the light liquid mangerite have probably strongly influenced the ultimate configuration of these plutonites. The close spatial association of anorthosite and jotunite, and the independent behaviour of the mangerites can be explained qualitatively in these terms.

Since $S_{i}$ and $S_{2}$ are commonly parallel to each other in the jotunites and the mangerites, it might well be that the movements of the plutonic complex with respect to the supracrustal rocks were not terminated before all rocks had solidified and metamorphism had taken place. In fact, it is conceivable that not only the stress field, but also the temperature was determined by the buoyant mass. We will return to this point on page 206.

If a buoyant mass reaches a strong impenetrable layer, or a layer less dense than itself, before equilibrium is restored, a laterally spreading »hat» forms (Ramberg, op. cit.).

Now, the profile of the Bouguer anomaly over the Morin Mass and its surroundings (Thompson and Garland, op. cit., p. 124) shows that the average density of the rocks underlying the area east of the Mass is considerably less than that west of the Mass, corresponding to the abundance of leucocratic granulites in the east, and paragneisses and marble in the west. Furthermore, the relatively light and strong quartzites of the LQF have remained intact around the Eastern Lobe, whereas they are fragmented and mixed with jotunites and mangerites near the top and west and south of the Main Body. 
In short, it is suggested that these conditions have lead to the asymmetric development of the Morin Mass: while the western part continued to rise, the eastern part spread laterally eastward and northeastward. These diverging movements originated in the zone where the Main Body merges with the Lobe, and where we now find evidence of ductile failure in the anorthosite (p. 184), a syncline in the overlying rocks (StCalixte Synform), and a troctolite sill (Pl. 1).

The question arises whether the Eastern Lobe was subsequently deformed together with the adjacent supracrustal rocks by »independent» orogenic forces. This possibility cannot be ruled out, but there are too many similarities between some of Ramberg's models and the major structures reconstructed by us, to be fortuitous. In particular, the rim syncline in the models and the Rawdon nappe are undoubtedly corresponding structures. Also, the restriction of coaxial refolds $\left(\mathrm{F}_{3}\right)$ to the immediate surroundings of the Anorthosite nappe corresponds to similar restricted occurrences near the spreading "hat» of some scale models (»second-order compression folds»: Ramberg, op. cit., p. 106).

Once it is assumed that gravity is the driving force in all large structures in which the anorthosite is involved, and that no recourse has to be taken to an independent lateral stress field, many seemingly unconnected phenomena become elements in one coherent whole.

(1) In the Anorthosite nappe and the rim of the Anorthosite diapir, the common polygonal shape of pyroxene grains and the flattening of the noritic bodies (Fig. 24) shows that spreading has proceeded in an essentially solid, crystalline, but recrystallizing rock, without interstitial liquid. The possibility of ductile behaviour of crystalline anorthosite is clearly demonstrated by the folds in Figure 34, and by the narrow anorthosite dikes mentioned on page 177 . The latter are porphyroclastic and have very finegrained blastomylonitic to eugranoblastic selvages but no chilled rim.
(2) The presence of interstitial liquid in the rising part, and its absence from the spreading part of the anorthosite mass can be attributed to relatively rapid cooling of the latter, owing to the combination of (i) its large contact area with the supracrustal rocks, and (ii) the absence of heat of crystallization of the jotunite-mangerite fraction.

(3) The gradual change in texture and structure across the plutonites, which was shown to be spatially related to the major structures can be related genetically to the movements that gave rise to these major structures. The sequence of shapes, dome - diapir - nappe, corresponds to the sequence of movements, rising - rising and beginning of spreading - spreading, which, in its turn, corresponds to the sequence of textures and structures extensively described before (pp. 177, 183-184).

(4) The curvature of the eastern boundary of the Lobe corresponds to similar curvatures of the spreading "hat» in the scale models. According to Ramberg (op. cit., pp. 107-108), outside the edge of the what», a contact zone is produced with compressive stress normal to the front of the »hat». This stress generates folds in the overburden with axes more or less aligned with the frontal edge. If the terms »hat» and »overburden» are replaced by "Anorthosite nappe» and »supracrustal rocks» respectively, Ramberg's account fits, word for word, our observations around the Eastern Lobe. The parallelism and the gradual congruent curvature of the boundary of the Lobe and $\pi$-axes, as well as the continuity of change of subarea fabrics within and without the Lobe (Pl. 2) leave little to be desired for a fitting hypothesis of the tectonic evolution of the Morin Mass and its surroundings.

\section{Tectonic correlations}

It was concluded that one main phase of deformation is responsible for the development of virtually all penetrative fabric elements, including the minor $F_{2}$-folds (p. 196). 
It is a small step to extend the hypothesis offered in the last section (point 4, p. 202) to the tectonic evolution of the entire area covered by Plate 2.

The increase in dispersion and the gradual change in modal orientation of $\mathrm{L}_{2}$ (or: $\mathrm{F}_{2}$-fold axes) could, in some indefinite way, be ascribed to increasing distance from the fold-generating force, $i$. $e$. the spreading anorthosite mass. Another equally speculative proposition would be to invoke the spreading of another buoyant mass situated somewhere east of the area under consideration. In that case, lateral spreading of the Anorthosite nappe east-northeastward and of this hypothetical mass northwestward would generate "waves» which would interfere in the intervening area, and be responsible for the changes in $a$ and $b$ shear axes in subhorizontal shear planes, as speculated upon on page 190.

In fact, a granite-syenite pluton underlies an area of 700 square kilometers just east of subarea $\mathrm{E}$, but, unfortunately, its northwestern boundary seems to be determined by a young fault - presumably the same fault that separates the Eastern Lobe from the St-Lawrence lowlands (Béland and Morin, 1959).

Work is in progress around this pluton to stem the flow of these rather fantastic speculations.

The fundamental influence of the distribution and behaviour of plutonic masses on the attendant deformation, as shown by our work, makes tectonic correlation on the basis of scattered measurements of fold axes and lineations, or even on the basis of scattered observations of stectonic style», far from reliable. Therefore, we shall not venture into any correlations between the tectonic evolution of the area east and the area west of the Morin Mass, the more so as the workers in the latter area seem to disagree greatly in their views (Dimroth, 1966; WynneEdwards, 1969).

\section{Discussion and conclusions}

A problem that kept us preoccupied was that of basement-cover relations since the reinterpretation of Adirondack geology by Walton and de Waard (1963). The continuity of the LacQuinn Formation around the Eastern Lobe (Pl. 1) resembles so much the coherent stratigraphy mapped by Walton in the eastern Adirondack highlands, that we were convinced of the applicability of the basement-cover relationships postulated by these authors. Furthermore, the participation of the anorthosite in a penninestyle nappe is strongly reminiscent of basementcover relations in polycyclic orogenic zones.

However, many of the relations subsequently found by us around the Main Body fit the relatively simple hypothesis of gravity-induced emplacement of a crystallizing magma quite well; much of our evidence supporting this hypothesis has to be twisted and turned to fit one involving any type of plutonic basement. The argument involves structural and stratigraphic criteria, as well as the petrogenesis of the plutonites. Therefore, we shall consider some aspects of the latter, and return to the basement-cover problem further on.

Anorthosites, leuconorites, jotunites, mangerites and quartz-mangerites of the Morin Mass and its surroundings resemble greatly those described by A. R. Philpotts (1966) for a small complex situated seventy kilometers northeast of the Mass (Belleau-Desaulniers area). His evidence, particularly the composition and variation in composition of plagioclase, and coexisting orthopyroxene and clinopyroxene, points to consanguinity of the entire suite as the best fitting hypothesis. On the basis of a study of rare earth abundances in an anorthosite and a mangerite, J. A. Philpotts et al. (1966) have modified this hypothesis by pointing out that assimilation of considerable amounts of material with "normal» abundances of europium (such as sedimentary rocks) has to be postulated if the man- 
gerite and anorthosite are to be considered cogenetic.

The relationships between the plutonites in and around the Morin Mass are not in contradiction with a comagmatic derivation, and until local detailed work shows the hypothesis to be untenable, we accept the comagmatic nature of the rock suite. (It should be noted that »comagmatic suite» is employed here in the wide and rather vague sense of a suite of rocks that formed from a magma that progressively changed in composition by any physical or chemical process).

In this connection, a feature of the Main Body merits special attention: the aligment of plagioclase megacrysts $\left(\mathrm{S}_{i}\right)$ and the cumulate textures of the least deformed anorthosite (p. 173). This feature is explicable in terms of magmatic crystallization, but is hard to reconcile with the formation of an anorthosite residuum by partial anatexis as proposed by de Waard (1967) for "Adirondack-type» anorthosites.

Experimentally, Green (1969) has shown that at high temperatures, and pressures up to 13.5 kilobars, either partial anatexis of anhydrous quartz-dioritic bulk compositions or fractional crystallization of an anhydrous quartz-dioritic magma ( $\sim$ andesite), could result in the formation of crystalline gabbroic anorthosite and a melt of broadly granodioritic composition. The choice between these alternatives is obvious for the Morin Mass and associated plutonites.

However, the question is whether a choice should be made between these alternatives. Green (op. cit.) chose the quartz-diorite on the basis of the estimated bulk composition of a number of anorthositic complexes. In fact, the estimates range from diorite to quartz-diorite and granodiorite, and most are computed from the areal (map-) abundances of lithological units considered to be comagmatic (e.g. Barth, 1933; Buddington, 1939; Osborne, 1936; Philpotts, 1966).
Irrespective of difficulties particular to the rock suite under consideration - e.g. resemblances between high-grade metamorphic rocks of plutonic and supracrustal origin - this method of estimation is unreliable. A somewhat similar method is employed in the modal analysis of thin sections and can be defended on the grounds that a thin section can be considered as representing a random plane in a body of rock. A map, however, is definitely not a random section of a rock body. For instance, it may well be that jotunite and mangerite formed only a cap topping the Morin Mass. In that case, differences in the level of erosion would have radically changed the areal abundances of the various rock types: a few hundreds of meters higher and jotunite-mangerite would have been the areally dominant association, whereas at depth the jotunite-mangerite suite may be absent.

This brings us to another question of importance in the petrogenesis of the anorthositemangerite suite: is anorthosite the most basic member of »the» parent magma?

From the shape of that part of the Morin Mass that we were able to reconstruct, it was deduced that gravity could have been the propelling force in its final emplacement. Gravity could have played an even more important role in the initial movement of the plutonic mass: if a hypothetical parent magma would have differentiated into rocks heavier than the overburden (e.g. pyroxenites, peridotites, troctolites) and into the lighter plutonic complex presently exposed, gravity could have brought about a complete separation of the dense from the light fraction. The initial rise of the liquid light fraction would have taken place relatively quickly in a dense crystalline environment, and the common objection against migration of the heavy fraction beyond the limits of the negative gravity anomaly associated with plutonic anorthosite masses (e.g. Berrangé, 1965) does not hold.

In fact, troctolites, olivine gabbros, and pyroxenites have been reported from a number 
of Precambrian anorthositic complexes, and their presence may not be »accidental» there. In the present area, the only occurrence of troctolite is in the form of a sill-like mass situated in the zone where the Main Body merges with the Eastern Lobe, and where other indirect evidence points to a relatively narrow zone of movement (p. 184). It is conceivable that recurrent movement along a deep fault brought up the troctolite from a level below the anorthosite (see Fig. 39). Inch-scale layering in the troctolite is interpreted as a magmatic depositional or flow fabric, whereas its folded, foliated and lineated nature indicates emplacement prior to or during the lateral spreading of the Anorthosite nappe.

Briefly, we envisage »Adirondack-type» anorthosites (Bridgewater ane Harry, 1968), such as the Morin Mass, as one of the products of crystallization of magmas (basaltic?) that were emplaced slowly and cooled slowly while significant assimilation of supracrustal material could take place. Depending on a number of factors (p. 201), gravity-induced movements during and subsequent to crystallization could bring about: (i) separation of the heavy fraction (ultrabasicbasic) from the light fraction (basic-acid), and (ii) further separation of the constituents of the light fraction (anorthosite-mangerite). If these processes are not interrupted by subsequent disturbances, each rock type would ultimately form homogeneous »sills» interstratified with the supracrustal rocks, at depths corresponding to their densities and the density of the overburden (see also Goguel, 1948, p. 482).

In contrast with the above type of anorthosites, those of layered intrusions (Bushveld, Stillwater) are products of crystallization of magmas that were emplaced rapidly at high levels of the earth's crust, and cooled rapidly without significant assimilation of supracrustal rocks. Even if a long time was available for subsequent rearrangement, the dimensions of the anorthosite layers are not sufficiently large, and plasticoviscous drag would be a very effective brake to any gravity-induced movement.
Undoubtedly, intermediate types between these extremes exist, and in any genetically meaningful classification of magmatic anorthosites account should be taken not only of the composition of the parent magma, but also of the tectonic level of development and emplacement of the anorthosites (Wegmann, 1953).

The foregoing discussion brings out that time (and »timing») is a determining factor in size, shape and associations of anorthosite bodies, as pointed out by Kranck (1961).

Plutonic anorthosite masses are almost (?) wholly confined to Precambrian areas. Their absence from younger portions of the earth's crust, deeply eroded or not, could be attributed to the great length of time needed for emplacement by buoyancy. However, this does not explain their relative scarcity in some very old portions of Precambrian shields. If indeed contamination of a basaltic substratum is a prerequisite for the potential development of abundant anorthosite (Michot, 1964), it may well be that Kranck (op. cit.) is correct in attributing a great value to the presumed slow development of geosynclines in some early but postArchean time. According to him, a long period of quiet accumulation of sediments (quartzites, limestones, pelites) would favour a gradual increase in temperature as the geosyncline subsided slowly, and there would be ample time for contamination of sediments in the basaltic subcrustal material.

On the other hand, differences in amount of late, Phanerozoic uplift and erosion between Precambrian terrains seem an other possibility to explain the presence or absence of plutonic anorthosites.

Returning to the basement-cover problem, there is no need to repeat the arguments in favour of the sintrusive» nature of the plutonites at their present level of exposure. With the acceptance of the cogenetic nature of the plutonic suite, we have - rightly or wrongly - elimi- 
nated some akward hypotheses, and there does not seem to be a feasible alternative. Rare sequences of events could be thought up to maintain the plutonic-basement hypothesis, but since such sequences always have to end with intrusion of the jotunite-mangerite fraction at the interface of cumulate-type anorthosite and supracrustal rocks, they serve no good geological purpose.

The geochemical hypothesis of "separate intrusions» of the Main Body and the Eastern Lobe (Papezik, 1965) might be exploited to postulate an anorthositic basement (Eastern Lobe), later invaded by a suite of plutonic rocks (Main Body and associated plutonites). But the gradual change in fabric over the entire plutonic complex makes this hypothetical sequence of events, based merely on $\mathrm{K} / \mathrm{Na}$ and $\mathrm{Fe} / \mathrm{Mg}$ ratios, indefensible.

A short section should be dedicated to the possible relations between deformation, metamorphism and intrusion.

Little is known about the structure of the area prior to emplacement of the plutonites; even less is known about the grade of metamorphism at that time.

Since we consider that the spreading of the anorthosite nappe was simultaneous with - was the cause of - the formation of $\mathrm{F}_{2}$-folds, the parallelism of mineral lineations $\left(\mathrm{L}_{2}\right.$ and $\left.\mathrm{L}_{2}\right)$ and $\pi$-axes can only be interpreted as due to highgrade metamorphism during the emplacement of the Morin Anorthosite Mass and its associated plutonites. Furthermore, the parallelism of $S_{i}$ and $S_{2}$ in jotunites and mangerites was interpreted (p. 201) as indicating that buoyant movement was not terminated before all rocks had solidified and metamorphism had taken place. The possibility was mentioned that not only the stress field but also the temperature was determined by the buoyant mass. There is little doubt that close to the Mass this was the case; the question is how far the thermal effect of the plutonites extended into the adjoining supracrustal rocks. A number of mineralogical "geothermometers» will have to be studied, at various distances from the Mass, to answer this question. A semi-quantitative theoretical treatment, similar to that by Fonteilles and Guitard (1968) might also be possible, but a large number of factors has to be considered. Briefly, the temperature around the rising mass imagined by us, would be determined by:

(a) temperature and thermal conductivity of the surroundings prior to intrusion,

(b) temperature, thermal conductivity, and rate of movement of the rising mass,

(c) extent of heat-generating processes in the rising mass: magmatic crystallization, and

(d) extent of heat-consuming processes in and around the rising mass: assimilation, metamorphic recrystallization.

It should be noted that the so-called »basement effect» (effet de socle) defined and treated by Fonteilles and Guitard (op. cit.), has many features in common with those expected near a rising, intrusive mass. If the relations between an intrusive mass and the intruded rocks are similar to those of basement and cover, as in the present case of the Eastern Lobe and the supracrustal rocks, it will be extremely difficult to distinguish the basement effect from that of a synkinematic contact-metamorphic aureole.

The reasons for believing that the metamorphic reaction responsible for the formation of garnet, quartz, and clinopyroxene (p. 179) took place after the metamorphic episode referred to above, are:

(1) Recrystallized, metamorphic orthopyroxenes are consumed (partly) by the reaction. In fact, garnet-clinopyroxene rims are better developed in granulated and recrystallized rocks than in those that are but slightly deformed.

(2) The reaction took place under static conditions as shown by the ubiquitous reaction rims. In particular, the occurrence of unstrained grains of quartz without preferred form-orientation in the symplectites stands in marked contrast with the common mozaics of strongly oriented Plättungsquarz. 
The slope of the reaction curve is positive in a pressure-temperature diagram (Green and Ringwood, 1967; Green and Lambert, 1965). Therefore, the formation of garnet, quartz, and clinopyroxene from plagioclase and orthopyroxene may have been caused by a decrease in temperature at constant pressure, or by an increase in pressure at constant temperature, or by a combination of changes in both pressure and temperature. Why the reaction has taken place in and around the Main Anorthosite Body between isograds 3 and 4 can be explained if the first possibility - a decrease in temperature at constant pressure - is accepted as a first approximation to the actual changes in physical conditions.

Namely, it is probable that after final emplacement and solidification of the main plutonic

Acknowledgments - We thank Professor E. H. Kranck (McGill University) for his encouraging interest throughout the unexpectedly long period that the work took for its completion. We are grateful to Professor John G. Ramsay (Imperial College, London), to Dr. Dugald M. Carmichael and Mr. S. T. Ahmedali (McGill University) for their criticism. mass, its temperature was higher and cooling was slower than elsewhere in the area. Thus sufficient time was available for the formation of garnet and clinopyroxene in and around the Main Body. On the other hand, the stability field of the garnet+clinopyroxene assemblage was quickly crossed during the relatively rapid cooling of the rocks away from the main plutonic mass, and the sluggish reaction (post-kinematic, anhydrous) occurred only very rarely and locally.

Also in the Adirondacks, rocks of the »clinopyroxene-almandine and hornblende-clinopyroxene-almandine subfacies» appear to occur in the proximity of the anorthosite massifs (de Waard, 1965 , p. 189). We wonder whether a similar explanation would fit these occurrences.

One of us (KS) wishes to thank Dr. J. Béland, chairman of the Départment de Géologie, Université de Montréal, for his and his Departement's hospitality.

This work is part of a special mapping project carried out under the auspices of the Quebec Department of Natural Resources. The National Research Council of Canada made funds available to complete the laboratory work (Research Grant A-7058 to JM).

\section{REFERENCES}

Adams, F. D. (1896) Geology of a portion of the Laurentian area lying to the north of the Island of Montreal. Geol. Surv. Canada, Ann. Rept. 1895, 8, pt. J.

American Commission on Stratigraphic Nomenclature (1961) Code of stratigraphic nomenclature. Bull. Amer. Assoc. Petroleum Geol. 47, pp. 852-853.

Argand, E. (1911) Les nappes de recouvrement des Alpes Pennines et leurs prolongements structuraux. Beitr. Geol. Karte Schweiz, neue Folge 31, pp. 1-26.

BALk, R. (1931) Structural geology of the Adirondack anorthosite. Min. Petr. Mitt. 41, pp. 308-434.

BARTH, T. F. W. (1933) The large pre-Cambrian intrusive bodies in the southern part of Norway. 16th Intern. Geol. Congr. Rept., pp. 297-309.

Beland, J. and Morin, M. (1959) Part of the Grenville sub-province. Quebec Dept. Nat. Resources, Map 1328 .
Berrange, J. P. (1965) Some critical differences between orogenic-plutonic and gravity-stratified anorthosites. Geol. Rundschau 55, pp. 617-642.

Berthelsen, A. (1960) Structural studies in the Precambrian of Western Greenland. Medd. om Grønland 123, 1.

Bridgewater, D. and Harry, W. T. (1968) Anorthosite xenoliths and plagioclase megacrysts in Precambrian intrusions of South Greenland. Medd. om Grønland 185, 2.

Buddington, A. F. (1939) Adirondack igneous rocks and their metamorphism. Geol. Soc. Amer., Memoir 7.

Dimroth, E. (1966) Deformation in the Grenville province between Gatineau and Petite Nation rivers, Quebec. N. Jb. Miner. Abh. 105, pp. 93-109.

- (1963) Chapleau-Kaine area. Unpublished manucript, Quebec Dept. Nat. Resources, Quebec, P. Q. 
Engel, A. E. (1956) Apropos the Grenville. Roy. Soc. Canada Spec. Publ. 1, pp. 74-96.

Fonteilles, M. and Guitard, G. (1968) L'effet de socle dans le métamorphisme. Bull. Soc. fr. Minéral. Cristallogr. 91, pp. 185-206.

Goguel, J. (1948) Introduction à l'étude méchanique des déformations de l'écorce terrestre. Mémoires Carte Géol. France. Imprimerie Nationale, Paris.

Green, D. H. and Lambert, I. B. (1965) Experimental crystallization of anhydrous granite at high pressures and temperatures. J. Geophys. Res. 70, pp. 52595268 .

- and Ringwood, A. E. (1967) An experimental investigation of the gabbro to eclogite transformation and its petrological applications. Geochim. Cosmochim. Acta 31, pp. 767-833.

Green, T. H. (1969) High-pressure experimental studies on the origin of anorthosite. Can. J. Earth Sciences 6, pp. $427-440$.

Haller, J. (1955) Der zentrale metamorphe Komplex von NE-Grønland. Medd. om Grønland 73, 3.

Kranck, E. H. (1961) The tectonic position of the anorthosites of eastern Canada. Bull. Comm. géol. Finlande 196, pp. 300-320.

Martignole, J. (1969) Relations chronologiques et structurales entre la Série de Grenville et la Série de Morin dans le Sud du Québec. Geol. Assoc. Canada Spec. Paper 5, pp. 183-188.

- (1967) Tectonique, intrusions, anatexie, dans les séries catazonales de la région de Shawinigan, P. Q. Guidebook, Geology of parts of eastern Ontario and western Quebec, Ann. Meeting. Geol. Assoc. Canada and Mineral. Assoc. Canada, Kingston, 1967, pp. $87-97$.

- and Schrijver, K. (1968) Découverte du disthène dans le Sud de la Province tectonique de Grenville (Bouclier canadien) et signification pétrogénétique de ce minéral dans le faciès granulite. C. R. Acad. Sc. Paris 267, pp. 1355-1357.

Мгснот, P. (1964) Le magma plagioclasique. Geol. Rundschau 54, pp. 956-976.

Osborne, F. F. (1949) Coronite, labradorite anorthosite, and dykes of andesine anorthosite, New Glasgow, P. Q. Trans. Roy. Soc. Canada, third series, section 4, 43, pp. 85-112.

- (1936) Lachute map area. Quebec Bureau Mines, Ann. Rept. 1936, pt. C.

Papezik, V. S. (1965) Geochemistry of some Canadian anorthosites. Geochim. Cosmochim. Acta 29, pp. $673-710$.

Philpotrs, A. R. (1966) Origin of the anorthositemangerite rocks in southern Quebec. J. Petrology 7, pp. $1-67$.
Philpotts, J. A. et al. (1966) Rare earth abundances in an anorthosite and a mangerite. Nature 212, pp. 805806.

Ramber G, H. (1967) Gravity, deformation and the Earth's crust. Academic Press, London.

Ramsay, J. G. (1967) Folding and fracturing of rocks. McGraw-Hill, New York.

Rose, E. R. (1960) Iron and titanium in the Morin anorthosite, Quebec. Geol. Surv. Canada Paper $60-11$.

SAVAGE, J. (1967) Tectonic analysis of Lechada and Curavacas synclines, Yuso basin, León, NW Spain. Leidse Geol. Meded. 39, pp. 193-247.

Schrijver, K. (1968) The Lac-Croche Plutonic Complex, Quebec: basement of Grenville paragneisses? Leidse Geol. Meded. 43, pp. $1-8$.

Srmmons, G. (1964) Gravity survey and geological interpretation, northern New York. Bull. Geol. Soc. Amer. 75, pp. 81-98.

de Sitter, L. U. (1964) Structural Geology. Second edition. McGraw-Hill, New York.

Thompson, L. G. D. and Garland, G. D. (1957) Gravity measurements in Quebec (south of latitude $52^{\circ} \mathrm{N}$ ). Publ. Dominion Observatory Ottawa 19, pp. 111167.

Thomson, J. E. (editor) (1956) The Grenville problem. Roy. Soc. Canada Spec. Publ. 1.

Tröger, W. E. (1967) Optische Bestimmung der gesteinsbildenden Minerale. Teil 2 Textband. Schweizerbart'sche Verlagsbuchhandlung, Stuttgart.

Turner, F. J. (1968) Metamorphic Petrology. McGrawHill, New York.

de WAARD, D. (1967) On the origin of anorthosite by anatexis. Proc. Kon. Ned. Akad. Wetensch. Amsterdam, series B, 70, pp. 411-419.

- (1965) The occurrence of garnet in the granulitefacies terrane of the Adirondack highlands. J. Petrology 6, pp. 165-191.

- and Romer, W. D. (1969) Chemical and petrologic trends in the anorthosite-charnockite series of the Snowy Mountain massif, Adirondack highlands. Amer. Mineral. 54, pp. 529-538.

- and Walton, M. S. (1967) Precambrian geology of the Adirondack highlands, a reinterpretation. Geol. Rundschau 56, pp. 596-629.

WA GER, L. R. and BRown, G. M. (1968) Layered igneous rocks. Oliver and Boyd Ltd, Edinburgh.

Walton, M. S. and de WaARD, D. (1963) Orogenic evolution of the Pre-cambrian in the Adirondack highlands, a new synthesis. Proc. Kon. Ned. Akad. Wetensch. Amsterdam, series B, 66, pp. 98-106.

Watznauer, A. (1968) Der Begriff »Granulit». Monatsberichte Deutschen Akad. Wissensch. Berlin 10, pp. $913-919$. 
Wegmann, E. (1953) Über gleichzeitige Bewegungsbilder verschiedener Stockwerke. Geol. Rundschau 41, pp. $21-33$.

WYNNE-EDWARDS, H. R. (1969) Tectonic overprinting in the Grenville province, southwestern Quebec. Geol.
Assoc. Canada Spec. Paper 5, pp. 163-182.

- et al. (1966) Mont Laurier and Kempt lake map-areas, Quebec. Geol. Surv. Canada Paper 66-32.

Manuscript received, January 19, 1970. 